\title{
Ice sheet advance, dynamics, and decay configurations: evidence from west central Scotland.
}

15

\section{Andrew Finlayson*, Jon Merritt, Mike Browne, Jo Merritt, Andrew McMillan, Katie} Whitbread $^{1}$

British Geological Survey, Murchison House, West Mains Road, Edinburgh, United Kingdom EH93LA

* Corresponding author. Tel.: +44(0) 1316500209.

E-mail address: afin@bgs.ac.uk (A. Finlayson)

${ }^{1}$ Current address: Department of Geographical and Earth Science, University of Glasgow, Glasgow, United Kingdom G12 $8 Q Q$

\begin{abstract}
A $3700 \mathrm{~km}^{2}$ area adjacent to the Firth of Clyde, Scotland, is examined to constrain the development and dynamics of the western central sector of the last British and Irish Ice Sheet. Results from geomorphological mapping, lithostratigraphic investigations, three-dimensional geological modelling and field observations are combined to produce an empirically constrained, five-stage conceptual model of ice sheet evolution. (A) Previously published dates on interstadial organic deposits and mammalian fossils suggest that the Main Late Devensian (MLD) (MIS 2) glaciation of central Scotland began after $35 \mathrm{ka}$ cal BP. During build-up, ice advanced from the western Scottish Highlands into the Clyde and Ayrshire basins. Glaciomarine muds and shelly deposits scavenged from the Firth of Clyde were redeposited widely as shelly tills and glacial rafts. Ice advance against reverse slopes generated, and subsequently overtopped, ice-marginal sediment accumulations. We hypothesise that some of these formed pre-cursor ridges which were moulded into suites of ribbed moraine during the glacial cycle. (B) Sustained stadial conditions at the Last Glacial Maximum (LGM) (c. 30 - 25 ka cal BP) resulted in development of a major dispersal centre over the Firth of Clyde and Southern Uplands. This dispersal centre locally preserved previously-formed subglacial bedforms, and fed a wide corridor of fast-flowing ice east towards the Firth of Forth. (C) Initial deglaciation promoted a substantial reconfiguration of the ice surface, with enhanced westward drawdown into the outer Firth of Clyde and eastward migration of an ice divide towards the Clyde-Forth watershed. (D) Renewed ice sheet thickening over the Firth of Clyde may have accompanied growth of the Irish Ice Sheet during the Killard Point Stadial (c. 17.1 - 15.2 cal ka BP); it was associated with limited bed modification. Subsequent ice sheet retreat was characterised by substantial meltwater production, ponding and erosion. (E) Late stages of MLD ice sheet retreat were punctuated by one or more significant ice margin oscillations. Discovery of De Geer moraines at the site of a former proglacial lake in western Ayrshire allows glacier flow at the ice margin to be approximated as $\leq 290 \mathrm{~m} \mathrm{a}^{-1}$ during one such oscillation. Such velocities were probably enabled by basal sliding and shallow sediment deformation. At this stage those parts of the MLD ice sheet margin that were grounded in the Firth of Clyde were extremely vulnerable to collapse. Final disintegration of glacier ice in the Clyde basin probably occurred early in the Lateglacial Interstadial (Greenland Interstadial-1), coinciding with marine incursion to c. $40 \mathrm{~m}$ above present day sea level.
\end{abstract}




\section{Introduction}

Detailed geomorphological investigations, aided by increasingly powerful remote sensing datasets, have revealed complex flow signatures from former ice sheets (e.g. Clark and Stokes, 2001; De Angelis and Kleman, 2007; McCabe, 2008; Greenwood and Clark, 2009a). Such evidence is essential in order to test and refine numerically-driven ice sheet models,

50 which can simulate dynamic cycles and major ice flow configuration changes (e.g. Boulton and Hagdorn, 2006; Hubbard et al., 2009). The last British and Irish Ice Sheet (BIIS) is now known to have undergone substantial changes in geometry and flow during its evolution (Bowen et al., 2002; Bradwell et al., 2008; Evans et al, 2009; Greenwood and Clark, 2009b). However, terrestrial evidence is fragmentary, and coherent, time transgressive reconstructions

55 are lacking for many key sectors. Interpretations conflict owing to the isolated nature of individual studies, and uncertainty remains over whether events identified in the geological record were local phenomena resulting from internal glacier readjustments, or ice sheet-wide events controlled by climatic response (e.g. Sissons, 1964, 1976; Paterson, 1974; McCabe et al., 2007b; Peacock et al., 2007).

60

This study attempts to address these issues for west central Scotland (Figs 1,2) - an area of some $3700 \mathrm{~km}^{2}$ which was subjected to interactions between major accumulation zones of the last BIIS. By combining geomorphological, lithostratigraphical, and three-dimensional geological modelling investigations with existing research, we reassess the palaeoglaciology

65 of this formerly dynamic ice sheet zone. Specifically, this paper aims to: (i) identify evidence for spatially and temporally variable ice flow patterns, major geometry changes, and oscillatory events that accompanied build up and decay of the BIIS in west central Scotland; (ii) take account of published evidence from surrounding areas to test for indicators of more widespread ice sheet reorganisation(s); (iii) provide a coherent, conceptual model of ice sheet 70 evolution for this zone of the last BIIS; and (iv) enable better understanding of the threedimensional distribution of glacigenic, glaciolacustrine and glaciomarine sediments beneath greater Glasgow required for applied geological investigations.

\section{Background}

75 This section reviews the key published evidence relating to the Main Late Devensian (MLD) ice sheet glaciation of west central Scotland. In this paper, dates are quoted in radiocarbon years and calibrated to calendar years before present where appropriate, using the curves of Stuiver et al. (2005) and Fairbanks et al. (2005). Radiocarbon ages from marine samples are quoted assuming a 400-year reservoir age correction, except where indicated otherwise. 
The western central lowlands of Scotland have been recognised as an area affected by complex ice-flow patterns since J. Geikie (1863) described it as the "debatable ground over which glaciers of the Highlands or Southern Uplands (Fig. 1) prevailed according to their contemporary strengths". Highland-sourced ice initially extended south-eastwards to the northern flanks of the Southern Uplands as suggested by the distribution of indicator erratics and the widespread occurrence of 'lower' tills of north-western provenance underlying 'upper' tills derived from the south (Price, 1975; Sutherland and Gordon, 1993). Southern Uplands ice became more dominant later, deflecting Highland ice both to the east and southwest. The easterly diverted flow left a strong imprint on the landscape of the Clyde basin, in 90 the form of extensive, drumlin assemblages (Rose, 1987; Hall et al., 1998; Rose and Smith, 2008).

Former changes in ice flow direction are particularly apparent in central Ayrshire where evidence from erratics, stratigraphy, cross-cutting striae and roches moutonées demonstrate that ice firstly flowed onshore towards the south-east and then offshore south-westwards (Richey et al., 1930). Highland-sourced ice initially penetrated at least as far south as Nith Bridge (Fig. 2), carrying shells that were probably scavenged from the Firth of Clyde (Holden and Jardine, 1980; Sutherland, 1993). This early, on-shore flow of ice resulted in widespread deposition of shelly tills and rafts of glaciomarine clay, notably at Afton Lodge and Greenock 100 Mains (Fig. 2) (Smith, 1898; Holden, 1977; Abd-Alla, 1988; Gordon, 1993a,b). Evidence for a later, onshore readvance of Highland-sourced ice at the latter locality (Holden, 1977) implies that active ice occupied the Firth of Clyde and Ayrshire Lowlands after the eastern central lowlands had deglaciated (Sutherland, 1984).

105 Most evidence for these switches in flow relates to the last, MLD glaciation when the BIIS is thought to have reached the continental shelf edge to the north-west of the British Isles and merged with ice from Fennoscandia in the North Sea Basin (Graham et al., 2007; Bradwell et al., 2008). However, there is an unusually high concentration of mammalian fossil occurrences and other organic remains within glacigenic sequences that have survived the 110 MLD glaciation, particularly in the Ayrshire Lowlands and the lower Clyde valley (Bishop and Coope, 1977; Sutherland and Gordon, 1993). Early age determinations from bones of woolly rhinoceros from Bishopbriggs (Rolfe, 1966) and reindeer antler fragments from Sourlie (Fig. 2) (Jardine et al., 1988) yielded ages of c. $27-30 \mathrm{ka}{ }^{14} \mathrm{C}$ BP. A revised age of $31.1 \mathrm{ka}{ }^{14} \mathrm{C}$ BP (c. $35 \mathrm{ka}$ cal BP) has recently been published for the Bishopbriggs sample, 115 following ultrafiltration pre-treatment (Jacobi et al., 2009). This age is similar to those obtained from organic remains within fully investigated interstadial profiles beneath till at Balglass (Fig.1) (Brown et al., 2007) and Sourlie (Bos et al., 2004). Collectively, these dates 
suggest that the MLD ice sheet did not become established in the area until after c. $35 \mathrm{ka} \mathrm{cal}$ $\mathrm{BP}$, contrary to the conclusions of Bowen et al. (2002) . However, numerical modelling 120 experiments simulate minor glacial advances into the area prior to the main sustained advance in the Late Devensian (Hubbard et al., 2009). Indeed, the moderately-weathered Lawthorn Diamicton that underlies the interstadial deposits at Sourlie, and the Ballieston Till Formation (see below), which occurs within concealed depressions beneath Glasgow, must relate to an earlier expansion of glacier ice.

125

There is general agreement that the MLD ice sheet withdrew towards the west and northwest during deglaciation of the area (Price, 1983; Sutherland, 1984). Ice-marginal lakes formed where ice impeded drainage, firstly on the watershed between the catchments of the Avon Water and River Irvine, in Glengavel (Fig. 2), where laminated glaciolacustrine silts occur to 130 an elevation of at least $205 \mathrm{~m}$ above sea level (a.s.l.) (Nickless et al., 1978). This lake came into existence shortly after Highland and Southern Uplands-sourced ice had separated (Phemister in Richey, 1926; McLellan, 1969; Martin, 1981). Water held within the upper Avon Valley merged with a much larger lake, 'Lake Clydesdale' (Bell, 1874), which eventually occupied the Clyde valley and its tributaries upstream of Glasgow. The level of

135 Lake Clydesdale probably dropped in stages as north-westward retreat of the ice margin in the lower Clyde Valley made available spillways to the east at progressively lower elevations of 200, 165, 102, and 85m a.s.1. respectively (Paterson et al., 1998, fig. 12). The lake finally drained eastwards via a col in the upper Kelvin valley at about $45 \mathrm{~m}$ a.s.l. (Forsyth et al., 1996; Hall et al., 1998).

140

Lake Clydesdale probably existed during the creation of the Main Perth Shoreline in the Forth estuary (Sissons and Smith, 1965; Sutherland, 1984), and possibly into the beginning of the Lateglacial Interstadial (GI-1) (Peacock, 1999, 2003). The timing, contemporary sea level and manner in which the late-glacial sea eventually invaded Lake Clydesdale is disputed (see 145 Peacock, 2003 for review), but it is generally accepted that the transgression had occurred by $13.1-12.5^{14} \mathrm{C}$ ka BP (based on uncorrected, reported ages from marine shells) (Peacock, 1971, 2003; Peacock et al., 1977; Browne et al., 1977; Rose, 2003). The presence of a radiocarbon plateau at this time, and uncertainty regarding the reservoir correction at the Greenland Stadial-2 (GS-2) to GI-1 boundary, preclude a more precise chronology based on $150 \quad{ }^{14} \mathrm{C}$ dates alone (Peacock, 2003). Final disintegration of ice blocking the Clyde estuary resulted in the level of Lake Clydesdale falling from $45 \mathrm{~m}$ to no less than $40 \mathrm{~m}$, the contemporary sea level (Peacock, 2003). Sea level then fell rapidly, but further discussion of the subsequent, complex sea-level history of the area is not presented here, nor discussion of events during the Loch Lomond Stadial (Greenland Stadial-1, GS-1), when ice readvanced 
155 from the Loch Lomond basin to the northwest of Glasgow (Rose et al., 1988; Evans, 2003; Rose and Smith, 2008).

\section{Lithostratigraphy of west central Scotland}

Despite the success of modern geomorphological analysis in distiguishing the relative ages of 160 landforms, it is essential also to consider the known sequence of deposits (lithostratigraphy) in order to determine a robust event stratigraphy. Detailed lithostratigraphical knowledge also underpins sophisticated three-dimensional modelling of Quaternary deposits (e.g. J.E. Merritt et al., 2007). The lithostratigraphy for the Clyde and Ayrshire basins presented here (Fig 3) develops that of Sutherland (1999) and follows a new top-down, nationwide framework

165 (McMillan et al., 2005, in press; www.bgs.ac.uk/lexicon).

The Clyde lithostratigraphy is based on formations proposed by Rose $(1981,1989)$ and Browne and McMillan (1989a). The lowermost Ballieston Till Formation consists of consolidated sandy silty clay diamicton with isolated boulders and pebbles. It is dark greyish 170 brown at depth, but reddish brown at the surface possibly due to weathering (oxidation). Sections in the till revealed numerous joints, many of which were striated and polished on their surfaces. Boreholes and temporary sections from Glasgow revealed up to $15 \mathrm{~m}$ of consolidated, laminated, unfossiliferous, silty glaciolacustrine clays with dropstones (Broomhill Clay Formation) overlying the Ballieston Till (Browne and McMillan, 1989a).

175 These authors suggested that the laminations are varves, representing $600-1000$ years of sedimentation. Importantly, these glaciolacustrine clays occur to depths of c. $25 \mathrm{~m}$ below present sea level, requiring a low contemporary sea level at the time of deposition. Where observed, the Broomhill Clay is overlain by the regional till of the area, the Wilderness Till Formation. However, in parts of northern Glasgow, the latter rests on bedded, bouldery 180 gravelly sands of the Cadder Sand Formation. These sands have yielded bones and teeth of woolly rhinoceros, (Rolfe, 1966). The Wilderness Till is described by Rose et al. (1988) as a defomation till, but it also includes tectonised thrust slices of sand and laminated clay from underlying units. In Glasgow, it is a sandy silty clay diamicton with pebbles and isolated boulders. The colour varies, depending on local bedrock. In eastern Glasgow the Wilderness

185 Till is overlain by the Broomhouse Sand and Gravel Formation, much of which forms icecontact topography (eskers, mounds, flat-topped kames and kettleholes). These deposits have been extensively removed for aggregate. The Broomhouse Sand and Gravel Formation includes deltaic sands and glaciolacustrine laminated clays (Ross Sand and Bellshill Clay members, respectively), which were deposited in an ice-dammed lake, 'Glacial Lake

190 Clydesdale' (Bell, 1874), whilst the MLD ice sheet margin retreated from the position of eastern Glasgow. 
In west central Scotland, raised glaciomarine deposits of late-glacial age are assigned to the Clyde Clay Formation (McMillan et al., in press) in which two principle members are recognised, the Paisley Clay and Linwood Clay. The former member generally comprises thinly laminated clays and silts with dropstones. This member is generally poor in fauna, only yielding the cold-water foraminifera Elphidium clavatum in significant numbers. It has been mapped in areas around the Clyde estuary up to altitudes of c. $40 \mathrm{~m}$ a.s.l. (Browne and McMillan, 1989a). The Linwood Clay Member is confined to western areas of the Clyde

200 estuary where it commonly overlies the Paisley Clay. It consists of more thickly bedded silts and clays with a richer faunal assemblage. (e.g. Browne and McMillan, 1989a; Peacock, 2003).

A gravelly silty clay diamicton, the Gartocharn Till Formation, occurs around the southern 205 shores of Loch Lomond, locally including marine foraminifera and broken marine shells entrained by erosion of units from the Clyde Clay Formation (Rose et al., 1988). Plant detritus found beneath the Gartocharn Till has been radiocarbon dated at $10.6{ }^{14} \mathrm{C} \mathrm{ka} \mathrm{BP}(\mathrm{c}$. $12.5 \mathrm{cal} \mathrm{ka} \mathrm{BP}$ ) (Rose et al., 1988), confirming that the till was deposited as glacier ice readvanced during the Loch Lomond Stadial (GS-1).

210

The Quaternary lithostratigraphy of central Ayrshire follows McMillan et al. (in press) and is based mainly on the succession that was exposed in an opencast coal site at Sourlie, near Irvine (Fig. 2) (Jardine et al., 1988; Sutherland, 1999). The site was excavated into the northwestern side of Sourlie Hill, one of a swarm of broadly eastward orientated drumlins. The

215 importance of the site lay in the discovery of thin lenses of organic material (Sourlie Organic Silt Formation) occurring between two units of till. These lenses yielded a very rich flora and fauna deposited within a shallow pond in a treeless, low-shrub to sedge-moss tundra environment, and included bones of woolly rhinoceros and reindeer. Radiocarbon dates on antler fragments, plant debris and bulk organic matter suggest a Middle Devensian age (Bos 220 et al., 2004).

The basal unit comprises up to $7.5 \mathrm{~m}$ of very stiff, dark grey, silty sandy stony clay diamicton ('lodgement till'), the Littlestone Till Formation, which locally encloses deformed sheets (glacial rafts?) of sand up to $7.5 \mathrm{~m}$ thick. The till is overlain by up to $3.5 \mathrm{~m}$ of unstratified, 225 clay-rich gravel and clayey sand (Lawthorn Diamicton Member of the Littlestone Till Formation), interpreted as an 'ablation deposit' by Jardine et al. (1988), but probably better described today as glacigenic debris flow deposits. The Lawthorn Diamicton is overlain by 
up to $5.5 \mathrm{~m}$ of the partially cross-stratified Armsheugh Sand and Gravel Formation that is interpreted by Jardine et al. (1988) to have formed as glaciofluvial outwash. The Middle 230 Devensian Sourlie Organic Silt Formation occupies shallow depressions within the surface of the sand and gravel. The organic deposits are overlain by up to $3.5 \mathrm{~m}$ of pinkish brown, very stiff, pebbly sandy silty clay diamicton containing clasts of local sandstone, mudstone, coal and dolerite, 'far travelled sedimentary, igneous and metamorphic rocks' and shell fragments, including sparse paired valves of marine molluscs yielding Late Devensian amino acid ratios 235 (Jardine et al., 1988). This unit, the Eglinton Shelly Till Member of the Wilderness Till Formation, is correlated here with other widespread occurrences of shelly till in Ayrshire (Smith, 1898; Sutherland and Gordon, 1993), that elsewhere contains rafts of cold-water marine silts and clays, notably at Afton Lodge, near Ayr (Gordon, 1993a). The uppermost glacigenic unit at Sourlie comprises up to $12 \mathrm{~m}$ of stiff, dark grey 'lodgement till', the

240 Auchenwinsey Till Member of the Wilderness Till Formation. It forms most of the drumlin into which the opencast site was excavated.

\section{Methods}

\subsection{Remote sensing evidence}

245 Remote sensing datasets were interrogated within ESRI Arc Map 9.2. Digital surface models (DSMs) and georectified 1:10,000 monoscopic aerial photographs were analysed to identify glacial landforms in the study area. The surface models, built from NEXTMap® Britain topographic data (1.5 $\mathrm{m}$ vertical and $5 \mathrm{~m}$ horizontal resolution) were illuminated from the NW and NE to ensure capture of landforms with differing alignments. The DSM was analysed at 250 several scales, ranging from 1:10,000 to 1:200,000. During larger-scale analyses, horizontal resolution was reduced to $50 \mathrm{~m}$. Within the Glasgow area two additional versions of elevation data were used. One was a hill-shaded digital terrain model (DTM), for which data are processed to smooth abrupt surface features (e.g. buildings) allowing clearer (but less accurate) visualisation of the ground surface. The second was the unprocessed, orthorectified

255 radar data, which was effective in picking out glacial landforms within built up areas.

\subsection{Three-dimensional geological evidence}

Over 60,000 borehole records exist for Glasgow and the surrounding area. The British Geological Survey (BGS) is currently creating a suite of three-dimensional Quaternary and 260 bedrock models, based on the borehole data (J.E. Merritt et al., 2005; J.E. Merritt et al., 2007) using the modelling software tool, GSI3D (Sobisch, 2000; Kessler et al., 2006). In this study, outputs from these three-dimensional geological models were used for two purposes: (i) to confirm the basic composition of landforms, thereby enabling more confident discrimination between true glaciogenic features and bedrock controlled features; and (ii) to aid 
265 interpretation and identification in areas where subglacial landforms are masked by younger deposits (Fig. 4), or modified at surface due to urban development. A comprehensive UK database containing borehole records (BGS Borehole Geology) was interrogated throughout the investigation to provide additional information about the surface and subsurface sediments in the mapping area.

270

\subsection{Field evidence}

The greater Clyde basin area was resurveyed in the field at 1:10,000 scale over a 5 year period in the 1980s. The programme also included investigation of sedimentological, geotechnical and palaeontological characteristics of sixteen cored boreholes, and studies from 275 numerous temporary sections. This work resulted in production of Quaternary geological maps of the region (Browne and McMillan, 1989b). These field data provide important constraints for the work presented here.

\subsection{Data compilation}

280 All landforms and mapped sediment distributions were captured in a spatially attributed ArcGIS $^{\odot}$ database. Landforms mapped include: ribbed moraine, streamlined bedforms, meltwater channels, moraine ridge complexes and narrow transverse ridges. Existing Quaternary geological maps of the area (e.g. British Geological Survey, 1987, 1993a, 1993b, 2002; Browne and McMillan, 1989b) were consulted throughout the study. A recently 285 compiled 2-D digital geological map of Britain at 1:50:000 scale (DiGMapGB 50) was interrogated in the GIS and forms the basis for mapped distributions of glaciofluvial, deltaic, and raised marine sediments, and areas where bedrock occurs at or near the surface.

\section{Results}

290 A glacial geological and geomorphological map of the greater Clyde basin is shown in Figure 5. Some detail is lost reproducing the map at this scale, and numerous smaller features such as minor meltwater channels and individual moraine crests, are not shown. It is intended that a detailed, larger format glacial geological and geomorphological map will be available elsewhere. The morphological, spatial and, where known, basic sedimentological 295 characteristics of landform assemblages are described below.

\subsection{Ribbed moraine:}

Suites of southwest to northeast aligned, broad transverse ridges occupy the Clyde and Ayrshire basins up to an elevation of c. $200 \mathrm{~m}$ a.s.1. These ridges are 0.4-1.2 km in width, $300 \quad 0.4-6.5 \mathrm{~km}$ in length and up to $40 \mathrm{~m}$ in height. On a morphological basis, the ridges can be described as ribbed moraine, and their dimensions are entirely consistent with those reported 
by Dunlop and Clark (2006). Occupying areas principally underlain by Carboniferous sedimentary rocks and basalts, the ribbed moraine maintain a long-axis alignment that does not concord with variations in bedrock strike. Three-dimensional geological models (e.g. Fig. 4) in the Clyde basin indicate that these ridges commonly consist of glacial sediments assigned to the Wilderness Till Fm; thus their form is not considered to be controlled by bedrock structure.

The ribbed moraine are extensively remoulded with development of, or modification into, 310 elongate streamlined bedforms (described below). A 50-m-long temporary section within a broader zone of drumlinised ribbed moraine ridges was described by McMillan and Browne (1983) and Browne and McMillan (1989a). Here, a 2- to 5-m thick surface carapace of redbrown sandy clayey till of the Wilderness Till Fm sharply truncates a series of underlying sediments (Fig. 6). The lower sediments comprise till, bedded gravels, sands and clay, and 315 form a series of thrust slices dipping steeply westwards. Two normal faults occur in these lower sediments, on the western side of the thrust stack.

\subsection{Streamlined bedforms:}

Streamlined bedforms are well developed within the Clyde and Ayrshire basins, around the 320 margins of the Southern Uplands, and to the southeast of the Lochwinnoch Gap (Figs. 2, 5). In the latter area they occur where till is thin and patchy, and locally are strike parallel to the gently dipping Clyde Plateau Volcanic Formation. In that locality, bedforms are probably influenced by bedrock structure. Cover of Quaternary sediments is much thicker over the basins to the north and south, which are underlain mainly by Carboniferous sedimentary

325 rocks. That bedforms in the Clyde Basin are of glacial origin is supported by threedimensional geological models, which show that the landforms principally consist of glacial sediments assigned to the Wilderness Till Fm (Fig. 4). Many of the streamlined bedforms in the basins are superimposed on, or consist of, re-shaped sections of the ribbed moraine (Fig. 7).

Numerous geomorphologically-based ice sheet reconstructions use the approach of grouping bedforms into coherent 'flowsets' or 'swarms' (e.g. Boulton and Clark, 1990; De Angelis and Kleman, 2007; Stokes et al., 2009; Greenwood and Clark, 2009a). The streamlined bedforms identified here can be broadly divided into six flowsets based on their geographical 335 distribution, trend, morphology and spatial relationships with other geomorphological features (Fig 8, Table 1):

\subsubsection{Flowset I}


Streamlined bedforms assigned to flowset-I comprise a suite of drumlins trending towards the

340 east and east-northeast, and are generally confined to the northeast side of the River Clyde. They have a mean length of $826 \mathrm{~m}$, and a mean elongation ratio (ER) of 3.7. Bedforms in this group have been described previously by Rose (1987) and Rose and Smith (2008).

\subsubsection{Flowset II}

345 Streamlined bedforms assigned to flowset-II comprise a more subdued assemblage of drumlins trending towards the north and north-northeast. These bedforms curve along the northwest margins of the Southern Uplands, showing a very slight divergence at the elevated ground to the north of Greenock Mains. They are distinct from flowset-I on the basis of shorter length (mean: $563 \mathrm{~m}$ ) and of lower ERs (mean 2.9). Flowset-II tentatively includes

350 two similarly aligned, but more isolated streamlined bedforms to the northeast of Corse Hill.

\subsubsection{Flowset III}

Flowset III comprises ice-moulded bedrock and crag-and-tail forms over higher elevations and drumlins in the lower basin areas. They are well-preserved, and trend in a south to west355 northwest direction, forming an overall convergent pattern towards the southwest (Fig. 8). Subsets (III-a - III-e) are identifiable within flowset-III on the basis of slight variations in alignment and differences in morphological characteristics. For example, subsets III-b and III-c have a considerably longer mean length $(>1 \mathrm{~km})$ (Table 1$)$. This probably reflects thinner till cover, and local concordance with strike of the gently dipping volcanic rocks.

360 Although some of these bedforms may be influenced by bedrock structure over higher elevations, a consistent convergent trend is maintained in the lower-lying sediment-filled basins. The transition between individual subsets is largely gradational; thus, they are all incorporated within flowset-III.

Flowset-IV comprises a small cluster of streamlined bedforms c. $12 \mathrm{~km}$ south from the Blantyreferme Moraine (see below). These bedforms trend in an east to east-southeast direction. They possess the shortest lengths (mean $321 \mathrm{~m}$ ) of all the flowsets identified (Table 1).

\subsubsection{Flowset $V$}

Flowset-V comprises a well-defined suite of streamlined bedforms trending towards the east. They are generally confined to the western side of the Kilmarnock Moraine Belt (Fig 8) (see below); only a few isolated bedforms occur on the immediate eastern side. Streamlined 375 bedforms belonging to flowset-V overprint those of flowset-III (Figs 8,9) 


\subsubsection{Flowset VI}

Flowset VI comprises well-defined drumlins trending in a southeast direction. They are confined to the Clyde basin, and extend eastward as far as the Blantyreferme Moraine (see below). Overprinting of flowset-VI bedforms onto the generally longer flowset-I bedforms is apparent in parts of the Clyde basin, a characteristic described by Rose and Letzer (1977) and Rose and Smith (2008).

\subsection{Glaciofluvial assemblages:}

Glaciofluvial assemblages described here include both moundy, kettled, ice-contact deposits and terraced outwash spreads, both assigned to the Broomhouse Sand and Gravel Formation. It is worthy of note that glaciofluvial deposits portrayed on BGS maps may include deltaic sequences that formed in ice-marginal or proglacial lakes; only widespread, fine-grained

390 deposits are generally identified as 'glaciolacustrine'. Major belts of glaciofluvial deposits occur principally in the valleys of the Clyde, Kelvin and Avon (British Geological Survey, 1993a, 1993b, 1994). Many of the deposits in the southeast of the area are associated with systems of north-easterly-descending ice-marginal meltwater channels, notably southeast of Eaglesham and south of Strathaven (Richey et al., 1930; Paterson et al., 1998), where they fall 395 from about 320 to $260 \mathrm{~m}$ a.s.1. (Fig. 10A). Further significant belts of mounds and undulating spreads of sand and gravel occur in the upper Ayr and Nith valleys (British Geological Survey, 1982). These deposits are also associated with coherent systems of ice-marginal meltwater channels, which in the upper Ayr valley descend from about 300 to $250 \mathrm{~m}$ a.s.1. towards the east. Further sets of eastward descending marginal meltwater channels exist in 400 the Nith valley at altitudes from about $300 \mathrm{~m}$ down to $200 \mathrm{~m}$ a.s.l.

\subsection{Moraine ridge complexes:}

Three major moraine complexes have been identified in the Ayrshire and Clyde basins, at Kilmarnock, Blantyreferme and Eaglesham respectively (Figs. 2, 5). The Kilmarnock 405 Moraine Belt (KMB, Fig. 5) extends for approximately $14 \mathrm{~km}$ in a south-southwest to northnortheast direction, and ranges from 5 to $20 \mathrm{~m}$ in height. To the northeast of Kilmarnock, the belt reaches a maximum width of nearly $800 \mathrm{~m}$, where it forms multiple crests. Borehole records indicate that at least part of the complex comprises clay and sandy clay, while records immediately northwest of the ridge reveal till interbedded with sandy clay. Flat terrain 410 immediately southeast of the complex is underlain by up to $7 \mathrm{~m}$ of sands, laminated silts and clays. 
The Blantyreferme Moraine (BM, Fig. 5) was first recognised by Clough et al. (1911). Forming a near-symmetrical, cross-valley ridge, it is aligned south-southwest to north-

415 northeast extending for over $2 \mathrm{~km}$, and reaching nearly $20 \mathrm{~m}$ in height. Field mapping has revealed the feature to be of variable lithology, comprising till, sand and gravel and also laminated clay and silt (Browne and McMillan, 1989a).

The Chapelton Moraine Belt (CMB, Fig. 5) comprises a string of ridges and mounds that lie 420 to the east of Eaglesham on the northern slopes of Corse Hill (Richey et al., 1930; Paterson et al., 1998). These landforms, which include esker fragments, were formed at the southern margin of Highland-sourced ice early in the deglaciation of the area. They descend eastwards from about 305 to $260 \mathrm{~m}$ a.s.l. and were described by Sissons $(1963,1964,1967 \mathrm{a})$ as part of his more widespread evidence for the supposed 'Perth Readvance' (Simpson, 1933).

425

A further, near-coherent chain of moraine ridges occurs in the upper Ayr valley, above Greenock Mains. Individual ridges, up to $250 \mathrm{~m}$ in length, extend from c. $4 \mathrm{~km}$ north of Greenock Mains eastward for c. $8 \mathrm{~km}$, declining in altitude from 310 to $270 \mathrm{~m}$ a.s.l. Suites of eastward declining, marginal meltwater channels occur on the northern and southern flanks of 430 the upper Ayr valley, at altitudes of about 305 to $270 \mathrm{~m}$ a.s.1. Those on the northern side merge with the moraine ridges to the north of Greenock Mains (Fig. 10B).

\subsection{Glaciolacustrine assemblages:}

Extensive spreads of fine-grained glaciolacustrine sediment of the Bellshill Clay Member 435 occur at surface southeast and east of the Blantyreferme Moraine (Fig. 5). Glaciolacustrine sediments also crop out locally on the western flanks of the Kelvin valley (Browne and McMillan, 1989a; Hall et al., 1988) and along the margins of the Irvine valley downstream of Darvel (Nickless et al., 1978).

440 The glaciolacustrine assemblages in the Clyde basin commonly pass up and laterally into flattopped, deltaic deposits of the Ross Sand Member (Browne and McMillan, 1989a; Martin, 1981). Formerly exposed sections revealed sands and gravelly sands forming dipping foresets of Gilbert-type deltas (Fig 11, A and B). The deltaic deposits locally exceed $20 \mathrm{~m}$ in thickness in the eastern Clyde basin (Browne and McMillan, 1989a).

\subsection{Narrow transverse ridges:}

Two suites of previously unreported, closely spaced, narrow, linear transverse ridges occupy parts of the lower Irvine valley (Fig. 12) and the southern entrance to the Lochwinnoch Gap. The former, situated on the western side of the KMB trend broadly from south-southwest to 
450 north-northeast, and the latter trend broadly west to east. Those in the lower Irvine valley occur between about $30 \mathrm{~m}$ and $150 \mathrm{~m}$ a.s.l., while those south of the Lochwinnoch Gap lie between about $35 \mathrm{~m}$ and $140 \mathrm{~m}$ a.s.l. The former have a mean width of $75 \mathrm{~m}$, a mean height of $2.4 \mathrm{~m}$, and generally possess a symmetrical cross-profile (Fig. 13). Many of the ridges are continuous for over $400 \mathrm{~m}$, maintaining their alignment across topographic undulations of up

455 to $20 \mathrm{~m}$ in height. No sections have yet been observed within any of the landforms. However, borehole evidence from the Kilmarnock area demonstrates that surface sediments in the area of these narrow ridges comprise silts, sands and till. In places, the narrow transverse ridges are clearly superimposed on streamlined bedforms assigned to flowset V (Fig 12).

\subsection{Raised marine deposits:}

The lithostratigraphy of raised marine deposits in the Clyde basin has been described above. Field mapping has identified deposits of the Paisley Clay Member occupying extensive areas of the Clyde basin up to c. $40 \mathrm{~m}$ a.s.l. (Browne and McMillan, 1989a). Three-dimensional geological modelling supports the field interpretation and reveals thick spreads of silts and 465 clay, often partially masking the underlying, drumlinised landscape (Fig. 4). Further discussion of the distribution of raised marine deposits and associated features is not presented here.

\section{Interpretation of events in west central Scotland}

470

\subsection{Pre-Late Devensian Glaciation}

Evidence for a pre-Late Devensian, MIS 4 or older glacial advance-retreat cycle has briefly been discussed in section 2. It led to the deposition of the Ballieston Till Formation in the Clyde basin, and the Littlestone Till Formation in Ayrshire; it probably involved a substantial

475 advance of ice from the northwest. The apparently weathered top of the Ballieston Till suggests that there was a significant period of exposure before deposition of the overlying, glacitectonised, thinly laminated, glaciolacustrine sediments of the Broomhill Clay Formation in the Bellshill area (Figure 11C).

\subsection{Late Devensian Glaciation; Stage A. (Fig.14A; build-up to LGM)}

If the laminae in the Broomhill Clay Formation are correctly interpreted as varves, at least 600 to 1000 years elapsed before emplacement of the overlying Wilderness Till Formation (Browne and McMillan, 1989a). These glaciolacustrine sediments may document ponding during the earliest stages of ice advance into the area. Their occurrence to depths of $25 \mathrm{~m}$ 485 below present sea level, suggests that at the contemporary relative sea level was at least $25 \mathrm{~m}$ 
lower than present because there is no known barrier that could have prevented marine invasion.

Instances exist where streamlined bedforms from each flowset are superimposed on the 490 ribbed moraine ridges (e.g. Fig 7). Therefore, ridge formation must have occurred prior to the earliest phases of preserved streamlining in the study area. Regional geological evidence (e.g. Price, 1975; Sutherland, 1984; Sutherland and Gordon 1993) (Fig. 15) along with numerical ice sheet models (Hubbard et al., 2009) indicate that initial MLD ice-sheet advance into the area was from the northwest, broadly perpendicular to the ribbed moraine. We suggest this

495 was the period of ribbed moraine formation (Fig 14A), when the ice front advanced against a reverse slope, building (then overtopping) sediment ridges through folding and thrusting of proglacial sediments. A similar mechanism is invoked for the formation of 'cupola hills' elsewhere (Benn and Clapperton, 2000; Benn and Evans, 1998). The sediments formerly exposed at Holmbrae Road in Glasgow (Fig. 6) (McMillan and Browne, 1983) are consistent

500 with this interpretation. Initial advance lead to thrusting of the gravel, sand and clay beds in the eastern side of the section. The two normal faults may have been activated during a minor ice margin retreat, prior to overriding and deposition of the upper (Wilderness) till. The concept that some ribbed moraine originate as overridden ice marginal moraines has been proposed by Möller (2006). However, rigorous investigation of the sediments is required to

505 test this hypothesis for these particular ribbed moraine suites.

That landforms from such an early stage of glaciation could survive is supported by preservation of Middle Devensian deposits in the area, together with the widespread occurrences of shelly diamicton (Eglinton Shelly Till) and glacial rafts of glaciomarine mud

510 that were most likely scavenged from the Firth of Clyde during this early build-up stage. Their survival was probably aided by the development of an ice divide over the Firth of Clyde during the LGM (see below), beneath which there was minimal subglacial landscape modification.

515 6.3. Late Devensian Glaciation; Stage B. (Fig. 14B; LGM)

The drumlins of flowset-I must have begun to form after ice in the Clyde basin had become sufficiently thick to over-top the main Clyde-Forth drainage divide, allowing fast, essentially non-topographically constrained ice flow beyond. A significant dispersal centre had developed over the Southern Uplands had occurred by this stage, contributing to deflection of 520 ice in the Clyde basin toward the east, as evidenced by the well documented Dubawnt-type train (cf. Dyke and Morris, 1988) of essexite erratics that were dispersed from their source 
near Lennoxtown (Fig. 15) into the Firth of Forth (Peach, 1909: Shakesby, 1978, Evans et al., 2005). Striae patterns (Paterson et al., 1998) (Fig. 5) also document this flow.

525 Streamlined bedforms belonging to flowset-II were formed by north-eastward flow towards the Firth of Forth, driven by thicker ice to the southwest. This flow would have deposited Southern Upland till, with north-orientated clasts over the lower shelly tills (possibly of the Eglington Shelly Till Member) as described at Nith Bridge (Holden and Jardine, 1980; Sutherland, 1993) (Fig 16).

530

\subsection{Late Devensian Glaciation; Stage C. (Fig.14C)}

Streamlined bedforms from flowset-III document convergent south-westward and westward flow into the Firth of Clyde, and are consistent with patterns of glacial striations in the north Ayrshire basin (Paterson et al., 1998) (Fig. 5). This evidence suggests that a major change in 535 the ice sheet configuration had occurred, largely caused by drawdown to the west. Subsets of flowset-III probably document a transgressive phase where part of the Southern Upland dispersal centre was scavenged by this increasing drawdown as ice flowed westward over the south of Arran. Westward transportation of Ailsa Craig erratics (Sissons, 1967a) (Fig. 15) would have occurred during this flow phase. By this stage, the north-eastward flow that

540 generated flowset-II (Fig 14B - see above) must have switched off, allowing eastward migration of the ice divide, beneath which minimal subglacial modification was occurring.

\subsection{Late Devensian Glaciation; Stage D. (Fig.14D)}

A further, substantial alteration in ice sheet configuration and local basal conditions is 545 indicated by the following suite of landforms: limited east-trending streamlining (flowset-IV), eastward descending marginal meltwater channels, eastward descending suites of ice contact glaciofluvial landforms (including the Chapelton Moraine Belt), and minor eastward-pushing morainic assemblages in the Ayr valley. Collectively, they demonstrate ice-divide migration back towards the west, coupled with ice-sheet thickening in the vicinity of the Firth of Clyde. 550 The configuration is roughly that originally proposed for the 'Perth Readvance' in central Scotland (Sissons, 1963, 1964, 1967b). Of note is the limited bedform development from this stage, with only a small patch of Group IV bedforms occurring in the east. A minor readvance is apparent in the Ayr valley near Greenock Mains where a coherent assemblage of meltwater channels and moraine ridges indicate a late, north-eastward push (Fig. 10B) 555 (Holden and Jardine, 1980). 
A subsequent phase of more persistent streamlining is indicated by bedforms assigned to flowset-V and VI. These bedforms are generally longer than those of flowset-IV to the east 560 (Table 1). Abrupt termination of flowset-V and VI just beyond (to the east of) the Kilmarnock and Blantyreferme moraine complexes demonstrates that the ice flow phase that generated them extended to these areas. This flow phase probably included, or was followed by ice margin stabilisation at the moraines. Cross-cutting of drumlins in the Glasgow area (e.g. Rose and Letzer, 1977) indicates that cessation of the formation of flowset-I drumlins must have occurred prior to formation of flowset-VI bedforms.

To the east of the Kilmarnock and Blantyreferme moraine complexes (which may or may not be contemporaneous features), vast suites of glaciolacustrine and deltaic sediments in the Clyde and Irvine valleys demonstrate existence of ice-dammed lakes. The narrow, closely570 spaced ridges observed in the Kilmarnock area (Figs. 5, 12) and to the west of the Lochwinnoch Gap (Fig. 5) are similar in morphology to De Geer moraines, which form at, or close to the grounding line of calving glaciers (e.g. Lindén and Möller, 2005). The scale of the landforms is consistent with that of De Geer moraines, as is their pattern trending across topographic undulations (e.g. Todd et al., 2007). Given the abundant evidence for ice-

575 dammed lakes in the area, and local borehole records of interbedded sands, silts and till, the landforms are interpreted as De Geer moraines.

A simple estimate of calving speed can be calculated across a hypothetical calving margin similar to the one indicated by the De Geer moraines at Kilmarnock. Warren and Kirkbride 580 (2003) described an empirical linear relationship between water depth $\left(D_{\mathrm{W}}\right)$ and calving speed $\left(U_{C}\right)$ for glaciers terminating in freshwater bodies:

$$
U_{C}=17.4+2.3 D_{\mathrm{w}}
$$

$585 \mathrm{D}_{\mathrm{W}}$ can be approximated from the c. $150 \mathrm{~m}$ a.s.l. upper altitude of De Geer moraines (proxy for lake surface altitude) and the base of the Ayr valley (30 m a.s.1.). Assuming a similar calving margin relationship, palaeo-calving rate is calculated to have been $293 \mathrm{~m} \mathrm{a}^{-1}$ across the deepest part of the lower Ayr valley. Under steady state conditions (ice front not retreating, nor advancing), ice velocity at the margin would have been c. $290 \mathrm{~m} \mathrm{a}^{-1}$. These 590 values are comparable with those of modern glaciers terminating in proglacial lakes on the eastern side of the South Patagonian Icefield (e.g. Warren and Aniya, 1999). Ice flow velocities of this order are consistent with the local development of well-preserved streamlined bedforms assigned to flowset-V (Figs. 5, 8). The survival, locally, of extended 
Devensian sequences suggests that fast flow was enabled by basal sliding, and a relatively 595 thin, near surface deforming layer.

The preservation of both pre-MLD sediments and landforms interpreted to have developed early in the MLD glaciation is intriguing. Both the Clyde and Ayrshire basins lay directly in the path of ice sheet advance, and were subjected to more than one phase of relatively fast

600 glacier flow (described above). Despite thick 'soft sediment' sequences occupying these basins, it seems unlikely that widespread bed deformation occurred at any one time. Rather, a mosaic (sensu Piotrowski et al., 2004) of deforming and stable spots (characterised by ice-bed separation and basal sliding) is envisaged, enabling some sediment/landform preservation.

605

\section{Towards a regional synthesis}

In order to put our results into a more regional context (Fig.17) we briefly compare and test our deductions with some of those published recently for surrounding segments of the former BIIS. Importantly, our history of events for west central Scotland is consistent with the 610 paradigm of a mobile, dynamic BIIS (Bowen et al., 2002; Bradwell et al., 2008; McCabe, 2008; Evans et al., 2009; Greenwood and Clark, 2009b).

Recent numerical modelling experiments (Hubbard et al., 2009) simulate initial ice advance from the northwest into the Clyde and Ayrshire basins, accompanied by independent ice cap

615 development over the Southern Uplands. Our hypothesis for pre-cursor ribbed moraine development partially through accumulation and over-riding of ice marginal sediments also requires Southern Uplands ice to have remained a confined, independent mass while northwest-sourced ice entered the Clyde and Ayrshire basins(Fig. 14A). Further support for this early configuration comes from erratic transport paths (Fig 15) where a distinct limit of 620 Highland-sourced erratics has been identified (Fig. 5) (Eyles et al., 1949). Coupling of the two ice masses is unlikely to have occurred until northwest-sourced ice reached at least the south-eastern fringes of the Ayrshire basin. The subsequent development of a substantial ice divide over Arran and the Firth of Clyde with eastward flow across central Scotland by the LGM (Fig. 17B) has similarities with a recent reconstruction for northern England (Evans et 625 al., 2009) in which ice sourced over southwest Scotland and the Lake District is driven eastwards through the Stainmore and Tyne gaps. Importantly, there is no evidence for eastward transport of Arran and Ailsa Craig erratics (Fig. 15), limiting the westernmost position of the ice divide to the vicinity of Arran. 
630 There is no direct evidence to constrain the timing of ice divide migration towards the east following the LGM (Fig. 17C). However, there is evidence of post LGM enhanced drawdown of ice towards shelf-edge fans on the continental shelf to the northwest (Bradwell et al., 2008) and into the Irish Sea basin (Eyles and McCabe, 1988; Roberts et al., 2007). Our reconstruction of westward flow over the North Channel towards Ireland at this time is 635 consistent with the view of Salt and Evans (2004). Post-LGM, convergent westward flow may have been similar to that of an ephemeral ice stream (cf. Stokes et al., 2009) responding to break up and calving offshore to the northwest of Ireland. This interpretation is consistent with the findings of Greenwood and Clark (2009b) that once the ice sheet was established, geometry was largely controlled by fast flow / streaming corridors, which in this instance 640 forced the ice divide to the east.

The past two decades have seen considerable advances towards understanding the dynamics and deglacial history of the Irish sector of the last BIIS, largely through the work of McCabe and co-workers (e.g. Knight and McCabe, 1997; McCabe et al, 1998, 2005, 2007a). Bedform

645 patterns demonstrate that an ice sheet dome existed in the vicinity of Lough Neagh for much of the glacial cycle (Fig. 17B,C,D) (Knight, 2002) and a variety of inverse ice sheet models reconstruct an ice ridge over the North Channel linking the Southern Uplands and Lough Neagh dispersal centres during, and following, the LGM (e.g Boulton et al., 1991, 2002). Two major readvances interrupted decay of the Irish Ice Sheet: the Clogher Head Readvance 650 (c. $15.0-14.2{ }^{14} \mathrm{C}, 18.5$ - $16.7 \mathrm{cal}$ ka BP), and the Killard Point Readvance (c. $14.2-13.0{ }^{14} \mathrm{C}$, $17.1-15.2 \mathrm{cal}$ ka BP), the latter believed to be a direct response to Heinrich Event 1 in the North Atlantic (McCabe et al., 1998; McCabe and Clark 2003; McCabe et al., 2007a). We speculate that the strong westward ice flow during stage C (Fig. 17C) may have been in operation during deposition of a moraine at Corvish, County Donegal, during the Clogher 655 Head Readvance (McCabe et al., 2007a).

Our interpretation of subsequent westward migration of the Forth-Clyde ice divide towards Kintyre followed by topographically constrained eastward ice flow (Fig. 17D), is consistent with aspects of the reconstruction by Salt and Evans (2004) (their stages F and G). Renewed, 660 climatically-driven ice sheet growth over northeast Ireland during the Killard Point Stadial has been suggested by McCabe et al. (1998), and is supported by recent cosmogenic exposure ages of $15.6{ }^{10} \mathrm{Be}$ ka BP from moraine sequences in north-western Ireland (Clark et al., 2009). It is possible that the thickening of ice over Arran and the Firth of Clyde deduced here occurred at a similar time (Fig. 17D). 
It is noteworthy that the ice limits during our Stage D (and stage 3 of Paterson et al., 1998) are consistent with the ice sheet configuration in central Scotland suggested by Sissons (1963, 1964, 1967b) during the hypothesised 'Perth Readvance'. All require the presence of a large ice mass over the Firth of Clyde during deglaciation. Evidence for a significant readvance at 670 Perth was questioned by Francis et al. (1970), Paterson (1974), Price (1983), and Sutherland (1984), and the concept was rejected by Sissons (1976). McCabe et al. (2007b) recently cited new evidence in support of a readvance at Perth, which they correlate with the Killard Point Stadial in Ireland, concluding that it indicated an ice-sheet wide response to North Atlantic climate forcing. However, the evidence at that location remains open to interpretation (see 675 comments by Peacock et al., 2007 and reply from McCabe et al., 2007c). The evidence presented here cannot support nor refute that a more widespread readvance of the eastern ice margin took place at this time. However, the configuration depicted (Fig. 14D, 17D) would have had the effect of isolating ice masses on the eastern side of the Clyde-Forth drainage divide from their western source, possibly leading to development of widespread ice 680 stagnation' glaciofluvial topography, initially cited as one piece of evidence for the readvance (c.f. Sissons 1964).

Local readvances have been proposed to have occurred during deglaciation at Blackrock Ridge, at the head of Loch Indaal, Islay (Peacock and Merritt, 1997), Stranraer (Charlesworth, 685 1926; Peacock and Everest, 2009), and at Armoy and east Antrim on the northeastern Irish coast (McCabe, 2008) We suggest that moraine building at Blantyreferme and Kilmarnock (Fig. 5), occurred during the same overall phase of events. Ice retreat from Loch Indaal occurred possibly only a few hundred radiocarbon years before the beginning of the Lateglacial Interstadial (GI-1) (Peacock, 2008), placing tentative chronological constraints on 690 these late ice margin oscillations. Work in progress suggests that the outer Firth of Clyde was probably deglaciated before the opening of GI-1, at c. 14.7 cal ka BP (J.D. Peacock, personal communication), with deglaciation of the Glasgow region occurring some time after.

The Irish record suggests radically different local ice sheet geometries during build-up and 695 decay (McCabe, 2008; Greenwood and Clark, 2009b). In contrast, the ice sheet decay geometry in west central Scotland is reconstructed to have been similar to the build-up configuration (Fig. 14A, E). This was likely a result of proximity to the western Highlands, where the ice sheet was well situated to survive rises in equilibrium altitude during initial warming. Thus, the western Highlands and parts of Argyll were able to remain an important source area nourishing late stage ice margin oscillations. 


\section{Summary of regional events}

Following ice sheet build up (Fig. 17A), a centre of relatively immobile ice existed over 705 Argyll and west central Scotland (Fig.14B). Ice from this centre later linked with dispersal centres over Lough Neagh, in Ireland, and over the hills of southwest Scotland and the Lake District. Ice was driven eastward towards the Firth of Forth and through the Stainmore and Tyne Gaps (Fig. 17C) (Evans et al., 2009). Ice divides then migrated both eastwards and southwards as a result of enhanced drawdown of ice towards shelf-edge fans on the

710 continental shelf, to the northwest, and into the Irish Sea basin (Fig.17C). This reorganisation severely reduced the power of eastward flow towards the Firth of Forth and resulted in the generally accepted, relatively early deglaciation of eastern Scotland. A reversal of ice flow also occurred within the Vale of Eden and Solway Lowlands.

715 A major ice-surface high and ice divide developed over the outer Firth of Clyde, possibly during the Killard Point Stadial of Ireland. The ice divide probably linked with dispersal centres over Lough Neagh and the Southern Uplands (Fig. 17D). The ice sheet surface now descended from west to east over west central Scotland. On southern fringes of the Southern uplands, ice flow became topographically constrained (Salt and Evans, 2004), extending into 720 the Solway Firth (Evans et al., 2009).

Subsequent local readvances at east Antrim, Armoy, Islay, Stranraer, Kilmarnock and Blantyreferme punctuated late stages of ice sheet decay. Whether these ice margin oscillations were synchronous and climatically driven, or diachronous and influenced by local 725 factors such as topography and glacier bed hydrology, is uncertain. The remaining ice mass is likely to have been extremely unstable during final retreat from the Clyde basin, with large portions of the bed below the contemporary sea level.

\section{10. Conclusions}

The main conclusions from this research are as follows:

1. Published dates on preserved interstadial organic deposits show that the Main Late 735 Devensian (MLD) (MIS 2) glaciation of central Scotland began after $35 \mathrm{ka}$ cal BP. Some deposits of an earlier glaciation (MIS 4 or older) occur locally within the Clyde and Ayshire basins.

2. During a sustained build-up phase, ice advanced from the western Scottish Highlands into 740 the Clyde and Ayrshire basins. Glaciomarine muds and shelly deposits scavenged from the Firth of Clyde were redeposited widely across Ayrshire. Ice advance against reverse slopes 
enabled the build up of marginal sediment sediment accumulations. Some of these accumulations probably formed pre-cursor ridges, moulded into suites of ribbed moraine by subsequent over-riding.

3. Sustained stadial conditions at the Last Glacial Maximum (LGM) (30-25 ka cal BP) resulted in development of a major dispersal centre over the Southern Uplands and deflection of Highland ice towards the east and northeast. Relatively immobile ice beneath an icesurface 'high' positioned over Ayrshire and the western Clyde basin, preserved previously750 formed subglacial landforms and fed a wide corridor of fast-flowing ice towards the Firth of Forth.

4. A substantial re-configuration of the ice surface over west central Scotland was caused by enhanced westward drawdown into the outer Firth of Clyde and eastward migration of an ice

755 divide towards the Clyde-Forth watershed. This reorganisation is tentatively correlated with the Clogher Head Readvance established in the north of Ireland (c. $15.0-14.2{ }^{14} \mathrm{C}, 18.5-16.7$ cal ka BP).

5. Renewed ice sheet thickening over the Firth of Clyde may have accompanied growth of 760 the Irish Ice sheet during the Killard Point Stadial (c. $14.2-13.0{ }^{14} \mathrm{C}, 17.1-15.2 \mathrm{cal}$ ka BP). Subsequent ice sheet retreat was initially characterised by substantial meltwater production, ponding and erosion.

6. One or more significant ice front oscillations occurred late during deglaciation. These were 765 nourished by elevated source areas in the western Highlands and Argyll, which were well placed to survive initial warming. The discovery of De Geer moraines in western Ayrshire allows ice margin velocity during one such oscillation to be calculated as $\leq 290 \mathrm{~m} \mathrm{yr}^{-1}$. These late oscillations probably occurred close to the opening of the Lateglacial Interstadial (GI-1).

7. Once the MLD ice sheet margin had retreated into the inner Firth of Clyde, it was extremely vulnerable to collapse, which may have occurred early in GI-1. It was accompanied by marine incursion of the lower Clyde Valley up to c. $40 \mathrm{~m}$ above present-day sea level.

\section{$775 \quad$ Acknowledgments}

This work was carried out as part of the BGS Clyde Urban Super Project (CUSP), a multidisciplinary study of the Clyde Basin, and is published with the permission of the 
Executive Director of the British Geological Survey, NERC. Doug Peacock and Marshall 780 McCabe are thanked for comments on an earlier version of this manuscript. Tom Bradwell, Diarmad Campbell, and two anonymous referees are thanked for their careful reviews.

785

790

795

800

805

810

815

820

825 


\section{References}

Abd-Alla, M.A.A.1988. Mineralogical and geochemical studies of tills in south-western Scotland. Unpublished PhD thesis, University of Glasgow.

Ballantyne, C.K. 2007. The Loch Lomond Readvance on north Arran: glacier reconstruction and palaeoclimatic implications. Journal of Quaternary Science, 22, 343-359.

Bell, D. 1874. On aspects of Clydesdale during the glacial period. Transactions of the Geological Society of Glasgow, 4, A 6369.

Benn, D.I., Evans, D.J.A., 1998. Glaciers and glaciation. Arnold, London

Benn, D.I., Clapperton, C.M. 2000. Pleistocene glaciotectonic landforms and sediments around central Magellan Straight, southernmost Chile: evidence for fast outlet glaciers with cold-based margins. Quaternary Science Reviews, 19, 591-612.

Bishop, W.W., Coope, G.R. 1977. Stratigraphical and faunal evidence for Lateglacial and early Flandrian environments in south-west Scotland. In:Gray, J.M., Lowe, J.J. (Eds.), Studies in the Scottish Lateglacial Environment. Pergamon, Oxford, pp 61-88.

Bos, J.A.A., Dickson, J.H., Coope, G.R., Jardine, W.G. 2004. Flora, fauna and climate of Scotland during the Weichselian Middle Pleniglacial - palynological, macrofossil and coleopteran investigations. Palaegeography, Palaeoclimatology, Palaeoecology, 204, 65-100.

Boulton, G.S., Clark, C.D. 1990. A highly mobile Laurentide ice sheet revealed by satellite images of glacial lineations. Nature, 346 (6827), 813-817.

Boulton, G.S., Peacock, J.D., Sutherland, D.G. 1991. Quaternary. In: Trewin, N.H. (ed.) The Geology of Scotland (3 ${ }^{\text {rd }}$ edition). The Geological Society, London, 503-543.

Boulton, G.S., Peacock, J.D., Sutherland, D.G. 2002. Quaternary. In: Trewin, N.H. (ed.) The Geology of Scotland (4 ${ }^{\text {th }}$ edition). The Geological Society, London, 409-430.

Boulton, G.S. \& Hagdorn, M. 2006: Glaciology of the British Isles Ice Sheet during the last glacial cycle: form, flow, streams and lobes. Quaternary Science Reviews, 25, 3359-3390.

Bowen, D.Q., Philips, F.M., McCabe, A.M., Knutz, P.C., Sykes, G.A. 2002. New data for the last glacial maximum in Great Britain and Ireland. Quaternary Science Reviews, 21, 89-101.

Bradwell, T., Stoker, M., Golledge, N.R., Merritt, J.W., Long, D., Everest, J., Hestvik, O.B., Hubbard, A., Finlayson, A.G., Mathers, H. 2008a. The northern sector of the Last British Ice Sheet: maximum extent and demise. Earth Science Reviews, 88, 207-226.

British Geological Survey. 1982. New Cumnock. Scotland Sheet 15W. Drift Geology. 1:50,000. Keyworth, Nottingham.

British Geological Survey. 1987. Irvine. Scotland Sheet 22W. Drift Geology. 1:50,000. Keyworth, Nottingham.

British Geological Survey. 1993a. Hamilton. Scotland Sheet 23W. Drift Geology. 1:50,000. Keyworth, Nottingham.

British Geological Survey. 1993b. Airdrie. Scotland Sheet 31W. Drift Geology. 1:50,000. Keyworth, Nottingham.

British Geological Survey. 1994. Glasgow. Scotland Sheet 30E. Drift Geology. 1:50,000. Keyworth, Nottingham.

British Geological Survey. 2002. Kilmarnock. Scotland Sheet 22E. Solid and drift Geology. 1:50,000. Keyworth, Nottingham.

Brown, E.J., Rose, J., Coope, R.G., Lowe, J.J. 2007. An MIS 3 age organic deposit from Balglass Burn, central Scotland: palaeoenvironmental significance and implications for the timing of the onset of the LGM ice sheet in the vicinity of the British Isles. Journal of Quaternary Science, 22, 295-308.

Browne, M.A.E., Harkness, D.D., Peacock, J.D., Ward, R.G., 1977. The date of deglaciation of the Paisley-Renfrew area. Scottish Journal of Geology, 13, 301-303.

Browne, M.A.E., McMillan, A.A. 1989a. Quaternary Geology of the Clyde Valley. British Geological Survey Research Report SA/89/1.

Browne, M.A.E., McMillan, A.A. 1989b. Geology for land use planning: Drift deposits of the Clyde valley, Volumes 1 and 2. British Geological Survey Technical Report, WA/89/78.

Charlesworth, J.K., 1926. The readvance marginal kame moraine of the south Scotland and some later stages of retreat. Transactions of the Royal Society of Edinburgh, 55, 25- 50.

Clark, C.D., Stokes, C.R. 2001. Extent and characteristics of the M'Clintock Channel Ice Stream. Quaternary International, 86, $81-101$. 
Clark, J., McCabe, A.M., Schnabel, C., Clark, P.U., McCarron, S., Freeman, S.P.H.T., Maden, C., Xu, S. 2009. Cosmogenic $10 \mathrm{Be}$ chronology of the last deglaciation of western Ireland, and implications for sensitivity of the Irish Ice Sheet to climate change. Geological Society of America Bulletin, 121, 3-16.

Clough, C.T., Hinxman, B.A., Grant Wilson, J.S., Crampton, C.B., Wright, W.B., Bailey, E.B., Anderson, F.M., Carruthers, R.G. 1911. The geology of the Glasgow district. Memior of the Geological Survey of Great Britian, Sheets (parts of) $30,31,22$ and 23 (Scotland). $720 \mathrm{pp}$.

Dawson, A.G., 1982. Lateglacial sea-level changes and ice limits in Islay, Jura and Scarba, Scottish Inner Hebrides. Scottish Journal of Geology, 18, 253-265.

De Angelis, H., Kleman, J. 2007. Palaeo-icestreams in the Foxe/Baffin sector of the Laurentide Ice Sheet. Quaternary Science Reviews, 26, 1313-1331.

Dunlop, P., Clark, C.D., 2006. The morphological characteristics of ribbed moraine. Quaternary Science Reviews 25, 16681691.

Dyke, A.S., Morris, T.F. 1988. Canadian Landform Examples - 7: drumlin fields, dispersal trains, and ice streams in arctic Canada. Canadian Geographer, 32, 86-90.

Evans, D.J.A. (Ed.). 2003: The Quaternary of the Western Highland Boundary: Field Guide. Quaternary Research Association, London.

Evans, D.J.A., Clark, C.D., Mitchell, W.A. 2005. The last British Ice Sheet: a review of the evidence utilised in the compilation of the Glacial map of Britain. Earth Science Reviews, 70, 253-312.

Evans, D.J.A., Livingstone, S.J., Vieli, A., Ó Cofaigh, C. 2009. The palaeoglaciology of the central sector of the British and Irish Ice Sheet: reconciling glacial geomorphology and preliminary ice sheet modelling. Quaternary Science Reviews, 28, 740-758.

Eyles, N., McCabe, A.M. 1989. The Late Devensian (<22,000 BP) Irish Sea Basin: The sedimentary record of a collapsed ice sheet margin. Quaternary Science Reviews, 8, 307-351.

Eyles, V.A., Simpson, J.B., MacGregor, A.G. 1949. Geology of Central Ayrshire. Memoir of the Geological Survey Scotland, HMSO, Edinburgh.

Fairbanks, T.W., Mortlock, R.A., Chiu, T-C. Cao Li, Kaplan, A., Guilderson, T.P., Fairbanks, T.W., Bloom, A.L. 2005. Radiocarbon calibration curve spanning 0 to 50,000 years $\mathrm{BP}$ on paired ${ }^{230} \mathrm{TH} /{ }^{234} \mathrm{U} /{ }^{238} \mathrm{U}$ and ${ }^{14} \mathrm{C}$ dates on pristine corals. Quaternary Science Reviews, 24, 1781-1796.

Forsyth, I.H., Hall, I.H.S., McMillan, A.A. 1996. Geology of the Airdrie District. Memoir for 1:50,000 Geological Sheet 31W (Scotland). British Geological Survey, HMSO. London.

Francis, E.H., Forsyth, I.H., Read, W.A. \& Armstrong, M., 1970. The geology of the Stirling district. Memoir of the Geological Survey of Great Britain, HMSO, London.

Geikie, J. 1863. On the phenomena of the glacial drift of Scotland. Transactions of the Geological Society of Glasgow, 1, 1-190.

Gordon, J. E. 1993a. Afton Lodge. In: Gordon, J.E., Sutherland, D.G. (Eds.), Quaternary of Scotland. Chapman and Hall, London, pp. 538-541.

Gordon, J.E. 1993b. Greenock Mains. In: Gordon, J.E., Sutherland, D.G. (Eds.), Quaternary of Scotland. Chapman and Hall, London, pp. 542-544.

Graham, A.G.C., Lonergan, L., Stoker, M.S. 2007. Evidence for late Pleistocene ice stream activity in the With Ground basin, central north Sea, from 3D seismic reflection data. Quaternary Science Reviews, 26, 627-643.

Greenwood, S.L., Clark, C.D. 2009a. Reconstructing the last Irish Ice Sheet 1: changing flow geometries and ice flow dynamics deciphered from the glacial landform record. Quaternary Science Reviews, 28, 3085-3100.

Greenwood, S.L., Clark, C.D. 2009b. Reconstructing the last Irish Ice Sheet 2: a geomorphologically-driven model of ice sheet growth, retreat and dynamics. Quaternary Science Reviews, 28, 3101-3123.

Hall, I.H.S., Browne, M.A.E., Forsyth, I.H. 1998. Geology of the Glasgow district. Memoir for 1:50,000 Geological sheet 30E (Scotland). British Geological Survey, HMSO, London.

Harkness, D.D., Wilson, H.W. 1979. Scottish Universities Research and Reactor Centre Radiocarbon Measurements III. Radiocarbon, 21, 203-56.

Holden, W.G. 1977. The glaciation of central Ayrshire. Unpublished PhD thesis, University of Glasgow.

Holden, W.G., Jardine, W.G. 1980. Greenock Mains and Nith Bridge. In: Jardine, W.G. (Ed) Field Guide to the Glasgow region. Quaternary Research Association, Cambridge, pp. 18-21. 
Hubbard, A., Bradwell, T., Golledge, N., Hall, A., Patton, H., Sugden, D., Cooper, R., Stoker, M. 2009. Dynamic cycles, ice streams and their impact on the extent, chronology and deglaciation of the British-Irish ice sheet. Quaternary Science Reviews, 28, 758-776.

Jacobi, R.M., Rose, J., MacLeod, A., Higham, T.F.G. 2009. Revised radiocarbon ages on woolly rhinoceros (Coelodonta antiquitatis) from western central Scotland:significance for timing the extinction of woolly rhinoceros in Britain and the onset of the LGM in central Scotland. Quaternary Science Reviews, 28, 2551-2556.

Jardine, W.G., Dickson ,J.H., Haughton, P.D.W., Harkness, D.D., Bowen, D.Q., Sykes G.A. 1988. A Late Middle Devensian Interstadial at Sourlie, near Irvine, Strathclyde. Scottish Journal of Geology, 24, 288-295.

Kessler, H., Mathers, S.J., Sobisch, H-G. \& Neber, A. 2006: GSI3D - The software and methodology to build systematic nearsurface 3-D geological models - Version 2. British Geological Survey Internal Report.

Knight, J. 2002. Bedform patterns, subglacial meltwater events, and Late Devensian ice sheet dynamics in north-central Ireland. Global and Planetary Change, 35, 237-253.

Knight, J. \& McCabe, A.M., 1997. Identification and significance of ice-flow transverse subglacial ridges (Rogen moraines) in north central Ireland. Journal of Quaternary Science 12, 519-534.

1000 Lindén, M., Möller, P. 2005. Marginal formation of De Geer moraines and their implications to the dynamics of grounding-line recession, Journal of Quaternary Science, 20, 113-133.

Lowe, J.J., Rasmussen, S.O., Björk, S., Hoek, W.Z., Steffensen, J.P., Walker, M.J.C., Yu, Z.C., the INTIMATE group. 2008. Synchronisation of palaeoenvironmental events in the North Atlantic region during the Last Termination: a revised protocol recommended by the INTIMATE group. Quaternary Science Reviews, 27, 6-17.

Martin, J.H. 1981. Quaternary glaciofluvial deposits in central Scotland: sedimentology and economic geology. Unpublished PhD Thesis. University of Edinburgh.

McCabe, A.M., Knight, J., McCarron, S.G., 1998. Evidence for Heinrich event 1 in the British Isles. Journal of Quaternary Science 13, 549-568.

1015 McCabe, A.M., Clarke, P.U. 2003. Deglacial chronology from County Donegal, Ireland: implications for deglaciation of the British - Irish ice sheet. Journal of the Geological Society, London, 160, 847-855.

McCabe, A.M., Clark, P.U., Clark, J. 2005. AMS ${ }^{14} \mathrm{C}$ dating of deglacial events in the Irish Sea Basin and other sectors of the British-Irish ice sheet. Quaternary Science Reviews, 24, 1673-1690.

McCabe, A.M., Clark, P.U., Clark, J., Dunlop, P. 2007a. Radiocarbon constraints on readvances of the British-Irish Ice Sheet in the northern Irish Sea Basin during the last deglaciation. Quaternary Science Reviews, 26, 1204-1211.

McCabe, A.M., Clark, P.U., Smith, D.E., Dunlop, P. 2007b. A revised model for the last deglaciation of eastern Scotland. Journal of the Geological Society, London, 164, 313 - 316.

McCabe, A.M., Clark, P.U., Smith, D.E., Dunlop, P. 2007c. Discussion on a revised model for the last deglaciation of eastern Scotland - reply. Journal of the Geological Society, London, 164, 1261-1263.

McLellan, A.G. 1969. The last glaciation and deglaciation of central Lanarkshire. Scottish Journal of Geology, 5, 248-268.

McMillan, A.A., Browne, M.A.E. 1983. Glaciotectonic structures at Bellshill, East end of Glasgow. Quaternary Newsletter, 40, $1-6$

1035 McMillan, A. A., Hamblin, R. J. O., Merritt, J W. 2005. An overview of the lithostratigraphical framework for the Quaternary and Neogene deposits of Great Britain (Onshore). British Geological Survey Research Report RR/04/04 38pp.

McMillan, A.A., Hamblin, R.J.O., Merritt, J.W. in press. A lithostratigraphical framework for onshore Quaternary and Neogene (Tertiary) superficial deposits of Great Britain and the Isle of Man. British Geological Survey Research Report. 367pp.

Merritt, J.E., Hardenberg, M., Monaghan, A., Browne, M., Loughlin, S. 2005. 3D model of the solid and superficial geology of 1:10,000 Sheet NS66SW (Rutherglen). British Geological Survey Internal Report.

Merritt, J.E., Monaghan, A., Entlewise, D., Hughes, A., Campbell, D., Browne, M. 2007. 3D attributed models for addressing environmental and engineering geoscience problems in areas of urban regeneration- a case study in Glasgow, UK. First Break, $25,79-84$.

Möller, P., 2006. Rogen moraine: an example of glacial re-shaping of pre-existing landforms. Quaternary Science Reviews 25, $362-389$.

Nickless, E.F.P., Aitken, A.M., McMillan, A.A. 1978. The sand and gravel resources of the country around Darvel, Strathclyde. Description of parts of 1:20,000 sheets NS 53, 54, 63 \& 64. Mineral Assessment Report 35. Institute of Geological Sciences. London. HMSO. 
Paterson, I.B. 1974. The supposed Perth Readvance in the Perth district. Scottish Journal of Geology, 10, 53-66.

Paterson, I.B., McAdam, A.D., MacPherson, K.A.T. 1998. Geology of the Hamilton District. Memior for 1:50,000 Geological Sheet 23W (Scotland). British Geological Survey, HMSO. London.

Peach, B.N. 1909. Boulder distribution from Lennoxtown, Scotland. Geological Magazine, 46, 26-31.

Peacock, J.D., 1971. Marine shell radiocarbon dates and the chronology of deglaciation in western Scotland. Nature, 230, 4345 .

Peacock, J.D. 1999. The pre-Windermere Inrestadial (Late Devensian) raised marine strata of eastern Scotland and their macrofauna: a review. Quaternary Science Reviews, 18, 1655-1680.

Peacock, J.D. 2003. Late Quaternary sea level change and raised marine deposits of the western Highland Boundary - A) The deglaciation of the lower Clyde valley: a brief review. In: Evans, D.J.A. (Ed.) The Quaternary of the Western Highland Boundary: Field Guide. Quaternary Research Association, London.

Peacock, J.D. 2008. Late Devensian palaeoenvironmental changes in the sea area adjacent to Islay, SW Scotland: implications for the deglacial history of the island. Scottish Journal of Geology, 44, 183-190.

Peacock, J.D., Graham, D.K., Robinson, J.E., Wilkinson, I. 1977. Evolution and chronology of Lateglacial marine environments at Lochgilphead, Scotland. In: Gray, J.M \& Lowe, J.J. (Eds.), Studies in the Scottish Lateglacial Environment, Pergamon, Oxford, pp. 83-100.

Peacock, J.D., Merritt, J.W. 1997. The Tynacoille-Blackrock ridge: a possible ice front position for a glacier occupying Loch Indaal. In: Dawson, A.G. \& Dawson, S, (Eds.), Islay and Jura: Field Guide, Quaternary Research Association, Cambridge, 6677.

Peacock, J.D., Armstrong, M., Browne, M.A.E., Golledge, N.R., Stoker, M.S. 2007. Discussion on a revised model for the last deglaciation of eastern Scotland. Journal of the Geological Society, London, 164, 1261-1263.

Peacock, J.D., Everest, J.D. 2009. Pre-late Devensian high-arctic marine deposits in SW Scotland. Scottish Journal of Geology, 46 , in press.

Piotrowski, J.A., Larsen, N.K., Junge, F.W. 2004. Reflections on soft subglacial beds as a mosaic of deforming and stable spots. Quaternary Science Reviews, 23, 993-1000.

Price, R.J. 1975. The glaciation of west-central Scotland - a review. Scottish Geographical Magazine, 91, 134-145.

Price, R.J. 1983. Scotland's environment during the last 30,000 years. Scottish Academic press, Edinburgh.

Richey, J.E. 1926. Lanarkshire, Ayrshire and Peebleshire. In: The Department of Scientific and Industrial Research, Summary of Progress of the Geological Survey of Great Britain and the Museum of Practical Geology for the Year 1925. HMSO. London.

Richey, J.E., Anderson, E.M., MacGregor, M.C. 1930. The Geology of north Ayrshire. Memoir of the Geological Survey, Scotland - Explanation of one-inch sheet 22. HMSO. Edinburgh

Roberts, D.H., Dackombe, R.V., Thomas, G.S.P. 2007. Palaeo-ice streaming in the central sector of the British-Irish Ice Sheet during the Last Glacial Maximum: evidence from the northern Irish Sea Basin. Boreas, 36, 115-129.

Rolfe, W.D.I. 1966. Woolly rhinoceros from the Scottish Pleistocene. Scottish Journal of Geology, 2, 253-258.

Rose, J. 1981. Field guide to the Quaternary geology of the south-eastern part of the Loch Lomond basin. Proceedings of the Geological Society of Glasgow, Sessions 122/123, 12-28.

Rose, J., 1987. Drumlins as part of a glacier bedform continuum. In: Menzies, J., Rose, J. (Eds.), Drumlin symposium. Balkema, Rotterdam, pp. 103- 116.

Rose, J. 1989. Stadial type sections in the British Quaternary. In: Rose, J. \& Schlüchter, C. (Eds) Quaternary type sections: imagination or reality? Balkema, Rotterdam.

Rose, J. 2003. Geilston: Lateglacial and Holocene sea level change. In: Evans, D.J.A. (Ed.) The Quaternary of the Western Highland Boundary: Field Guide. Quaternary research Association, London.

Rose, J., Letzer, J.M., 1977. Superimposed drumlins. Journal of Glaciology, 18, 471- 480.

Rose, J., Lowe, J.J., Switsur, R. 1988. A radiocarbon date on plant detrius beneath till from the type area of the Loch Lomond Readvance. Scottish Journal of Geology, 24, 113-124.

Rose, J., Smith, M.J. 2008. Glacial geomorphological maps of the Glasgow region, western central Scotland. Journal of Maps, 399-416.

Salt, K.E., Evans, D.J.A., 2004. Scottish Landform Example 32: Superimposed subglacially streamlined landforms of southwest Scotland. Scottish Geographical Journal, 120, 133-147. 
Shakesby, R.A., 1978. Dispersal of glacial erratics from Lennoxtown, Stirlingshire. Scottish Journal of Geology, 14, 81-86.

Shotton, F.W., Brundell, D.J., Williams, R.E.G. 1970. Birmingham University radiocarbon dates IV. Radiocarbon, 12, 385-399.

Simpson, J.B., 1933. The late glacial readvance moraines of the Highland border west of the River Tay. Transactions of the Royal Society of Edinburgh, 57, 633- 645.

Sissons, J.B., 1963. The Perth readvance in central Scotland. Part I. Scottish Geographical Magazine, 79, 151-163.

Sissons, J.B., 1964. The Perth readvance in central Scotland. Part II. Scottish Geographical Magazine, 80, 28-36.

Sissons, J.B. 1967a. The evolution of Scotland's scenery. Oliver and Boyd. Edinburgh.

Sissons, J.B. 1967b. Glacial stages and radiocarbon dates in Scotland. Scottish Journal of Geology, 3, 175- 181.

Sissons, J.B. 1976. The Geomorphology of the British Isles - Scotland. Methuen, London.

Sissons, J.B., Smith, D.E. 1965. Peat bogs in a postglacial sea and a buried raised beach in the western part of the Carse of Stirling. Scottish Journal of Geology, 1, 247-255.

Smith, J. 1898. The drift or glacial deposits of Ayrshire. Transactions of the Geological Society of Glasgow, 11 (Supplement), $1-134$.

Sobisch, H-G. 2000. Ein digitales raeumliches Modell des Quartaers der GK25 Blatt 3508 Nordhorn auf der Basis vernetzter Profilschnitte. Shaker Verlag, Aachen. 113 pp.

Stokes, C.R., Clark, C.D., Storrar, R. 2009. Major changes in ice stream dynamics during deglaciation of the north-western margin of the Laurentide Ice Sheet. Quaternary Science Reviews, 28, 721-738.

Stuiver, M., Reimer, P.J., Reimer, R.W. 2005. CALIB 5.0.1 (Computer program and documentation). Available from: /http://radiocarbon.pa.qub.ac.uk/calib/.

Sutherland, D.G., 1984. The Quaternary deposits and landforms of Scotland and the neighbouring shelves—a review. Quaternary Science Reviews, 3, 157-254.

Sutherland, D.G. 1986. A review of Scottish marine shell radiocarbon dates, their standardization and interpretation. Scottish Journal of Geology, 22, 145-164.

Sutherland, D.G. 1993. Nith Bridge. In: Gordon, J.E., Sutherland, D.G. (Eds.), Quaternary of Scotland. Chapman and Hall, London, pp. 541-542.

Sutherland, D.G. 1999. Scotland. In: Bowen, D.Q. (Ed.), A revised correlation of Quaternary deposits in the British Isles. Geological Society Special Report No. 23. The Geological Society, Bath, pp. 99-114.

Sutherland, D.G., Gordon, J.E. 1993. Western central lowlands. In: Gordon, J.E., Sutherland, D.G. (Eds), Quaternary of Scotland. Chapman and hall, London, pp. 535-556.

Thomas, G.S.P., Chiverrell, R.C., Huddart, D. 2004. Ice marginal depositional responses to readvance episodes in the Late Devensian glaciation of the Isle of Man. Quaternary Science Reviews, 23, 85-106.

Todd, B. J., Valentine, P. C., Longva, O., Shaw, J. 2007. Glacial landforms on the German Bank, Scotian Shelf: evidence for Late Wisconsinan ice-sheet dynamics and implications for the formation of De Geer moraines. Boreas, 36, 148-169.

Warren, C., Aniya, M. 1999. The calving glaciers of southern South America. Global and Planetary Change, 22, 59-77.

Warren, C.R., Kirkbride, M. P. 2003. Calving speed and climatic sensitivity of New Zealand lake-calving glaciers. Annals of Glaciology, 36, 173-178. 


\section{Figure Captions}

Figure 1. Regional context. Box (labelled Figs. 2, 5, 14) shows location of study area in west 1200 central Scotland. Proposed former glacier ice limits and ages from Sissons (1967b), Dawson (1982), Rose et al. (1988), Peacock and Merritt (1997), McCabe et al. (1998, 2003), Thomas et al. (2004), Ballantyne (2007), and McCabe (2008). Key place names are shown.

Figure 2. Topography of study area and place names mentioned in text. Locations of

1205 subsequent figures are shown. Hill-shaded digital surface model built from Intermap Technologies NEXTMap ${ }^{\circledR}$ Britain topographic data. Northwest illumination.

Figure 3. Simplified lithostratigraphy for the period spanning the Main Late Devensian glaciation for the Clyde and Ayrshire basins. Based on McMillan et al. (2005, in press). For 1210 clarity only formations of primary relevance to this study are included. Fm - Formation, Mbr - Member. GICC05 - Greenland Ice Core Chronology 2005 events, after Lowe et al. (2008).

Figure 4. Three-dimensional Quaternary geological models revealing basic composition of geomorphological features in Glasgow area. A. Fence diagram revealing three-dimensional 1215 geology of Erskine - Renfrew area. Note drumlins entirely comprise sediments of the Wilderness Till Formation (in blue). Cross sections are based on borehole records. Vertical sticks represent individual boreholes B. Complete three-dimensional geological model for central Glasgow area showing Paisley Clay Mbr draped over drumlins comprising Wilderness Till Fm. C. Three dimensional geological model of Paisley area. Paisley Clay Formation 1220 sediments (in green) and alluvial sediments (in yellow) are removed to more clearly reveal bedforms in the Wilderness Till Formation (blue). All images are vertically exaggerated between 5 and 10 times.

Figure 5. Glacial geomorphology and geology of the Clyde and Ayrshire basins. Erratic 1225 limits from Eyles et al. (1949) and glacial striations from Paterson et al. (1998).

Figure 6. Temporary section within zone of drumlinised ribbed moraine at Holmbrae Road, Glasgow. Ice flow direction inferred from regional streamlining and sense of compression.

1230 Figure 7. Streamlined bedforms superimposed on ribbed moraine. See text for description. Hill-shaded digital surface models built from Intermap Technologies NEXTMap ${ }^{\circledR}$ Britain topographic data. Northwest illumination. 
Figure 8. Streamlined bedforms and flowsets identified in this study. fs - flowset.

1235

Figure 9. Cross cutting of streamlined bedforms in the Ayshire basin to the west of Kilmarnock.

Figure 10. A. Ice-marginal meltwater channels clearly descending towards the NE, to the 1240 south of Strathaven. B. Assemblage of moraine ridges and NE declining marginal meltwater channels in the vicinity of Greenock Mains. White arrows denote inferred final palaeo-ice flow direction. Hill-shaded digital surface models built from Intermap Technologies NEXTMap ${ }^{\circledR}$ Britain topographic data. Northwest illumination.

1245 Figure 11. Deposits associated with ice-dammed lakes in the Clyde basin. Deltaic sediments of the Ross Sand Mbr revealed in former sand and gravel pits near Bishopbriggs (A) and Hamilton (B). Photos from BGS archive image base. C. Lithostratigraphy including surface and buried glaciolacustrine deposits, revealed in the BGS Bellshill borehole.

1250 Figure 12. A. Hill-shaded digital surface model, built from Intermap Technologies NEXTMap ${ }^{\circledR}$ Britian topographic data, revealing narrow transverse ridges in the vicinity of Kilmarnock. Note overprinting of ridges on streamlined bedforms. B. Interpretation of same area.

1255 Figure 13. Cross-profile data extracted from the digital surface model revealing dimensions of the narrow transverse ridges.

Figure 14. Reconstructed stages, showing the evolution of the last BIIS in west central Scotland. See text for discussion. Hill-shaded digital surface models built from Intermap 1260 Technologies NEXTMap ${ }^{\circledR}$ Britain topographic data. Northwest illumination.

Figure 15. Erratic transport paths in SW Scotland. From Eyles et al. (1949) and Sissons (1967a). Note, erratic paths do not imply contemporaneous flow. Rectangle delimits main study area as shown in Figs. 2 and 5.

Figure 16. Section at Nith Bridge, from Holden and Jardine, (1980).

Figure 17. Proposed evolution of the western sector of the last BIIS. Arrows denote palaeoice flow directions. Dashed lines indicate approximate positions of ice divides. See text for 1270 discussion. 
Table 1. Morphological characteristics of streamlined bedforms in study area. ER elongation ratio, St Dev - standard deviation.

1275

1280

1285

1290

1295 


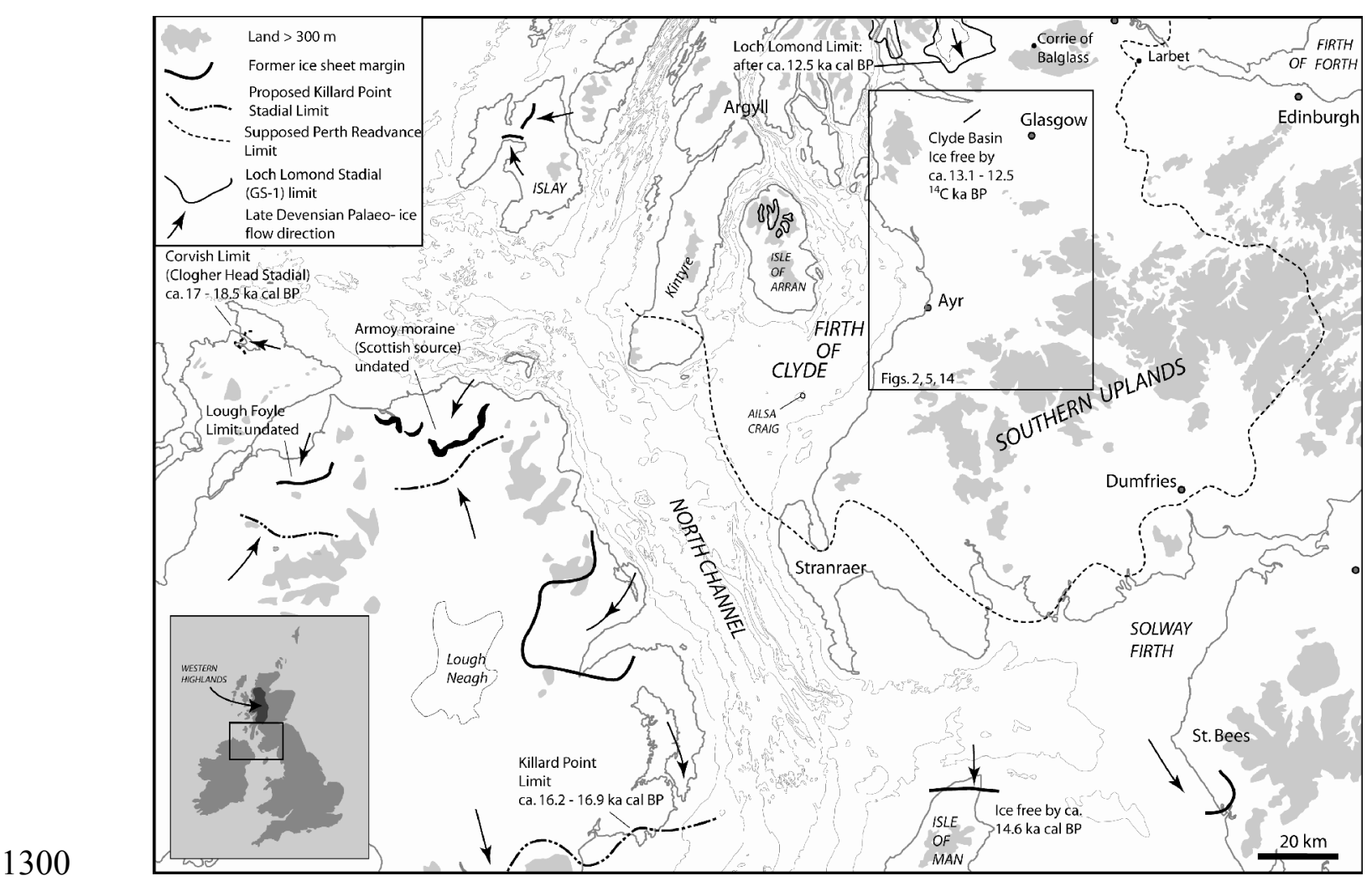

Fig. 1 


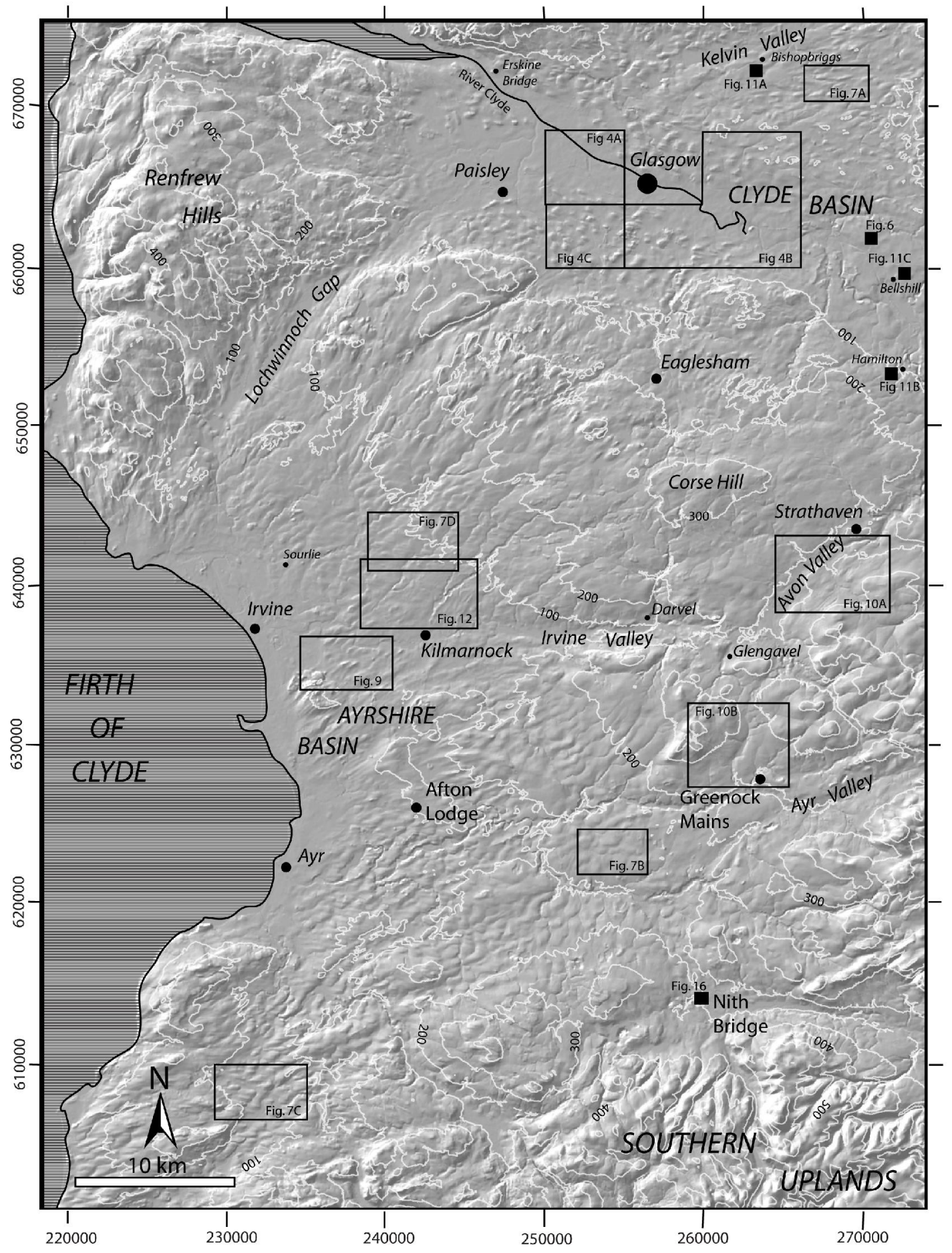

Fig. 2 


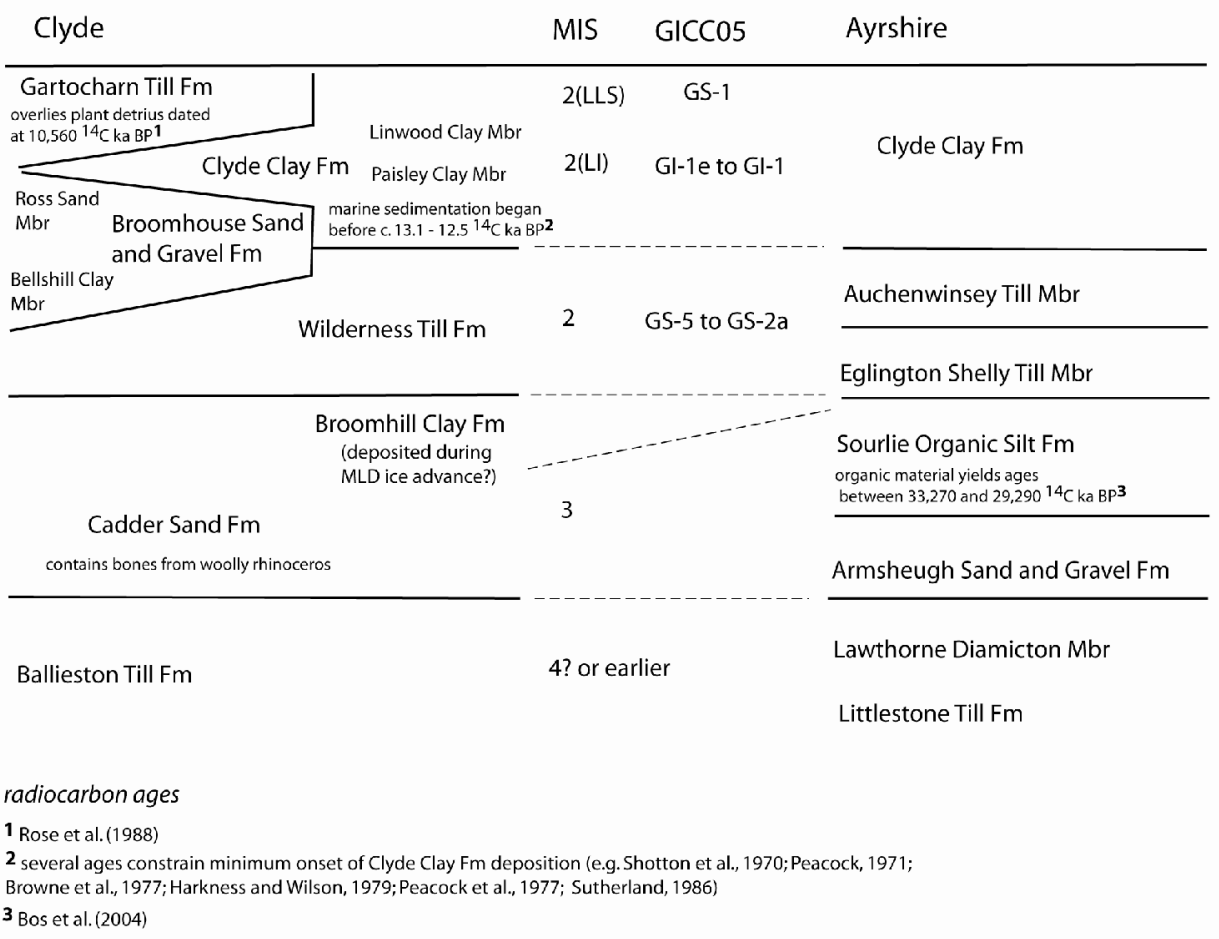

Fig. 3 


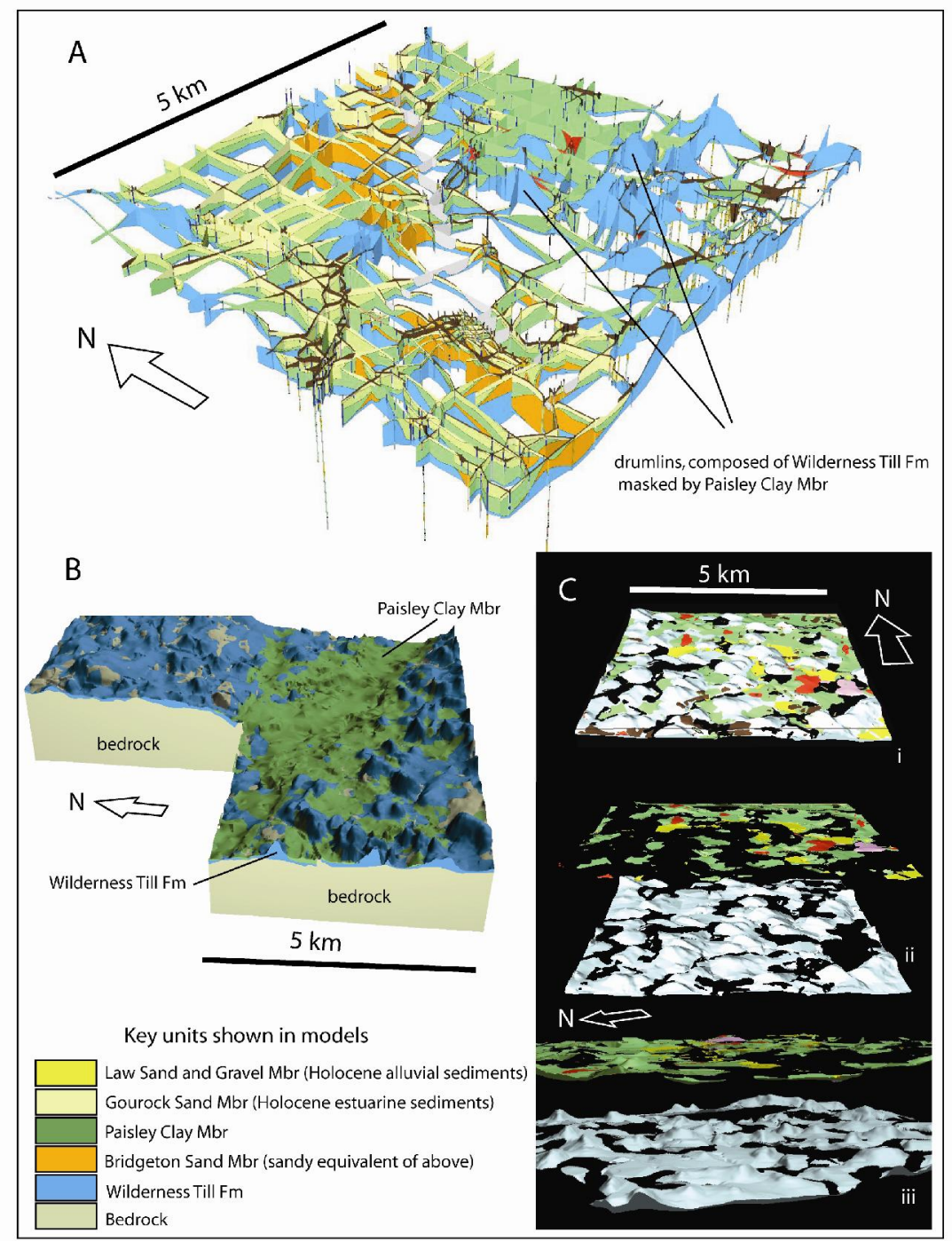

Fig. 4 


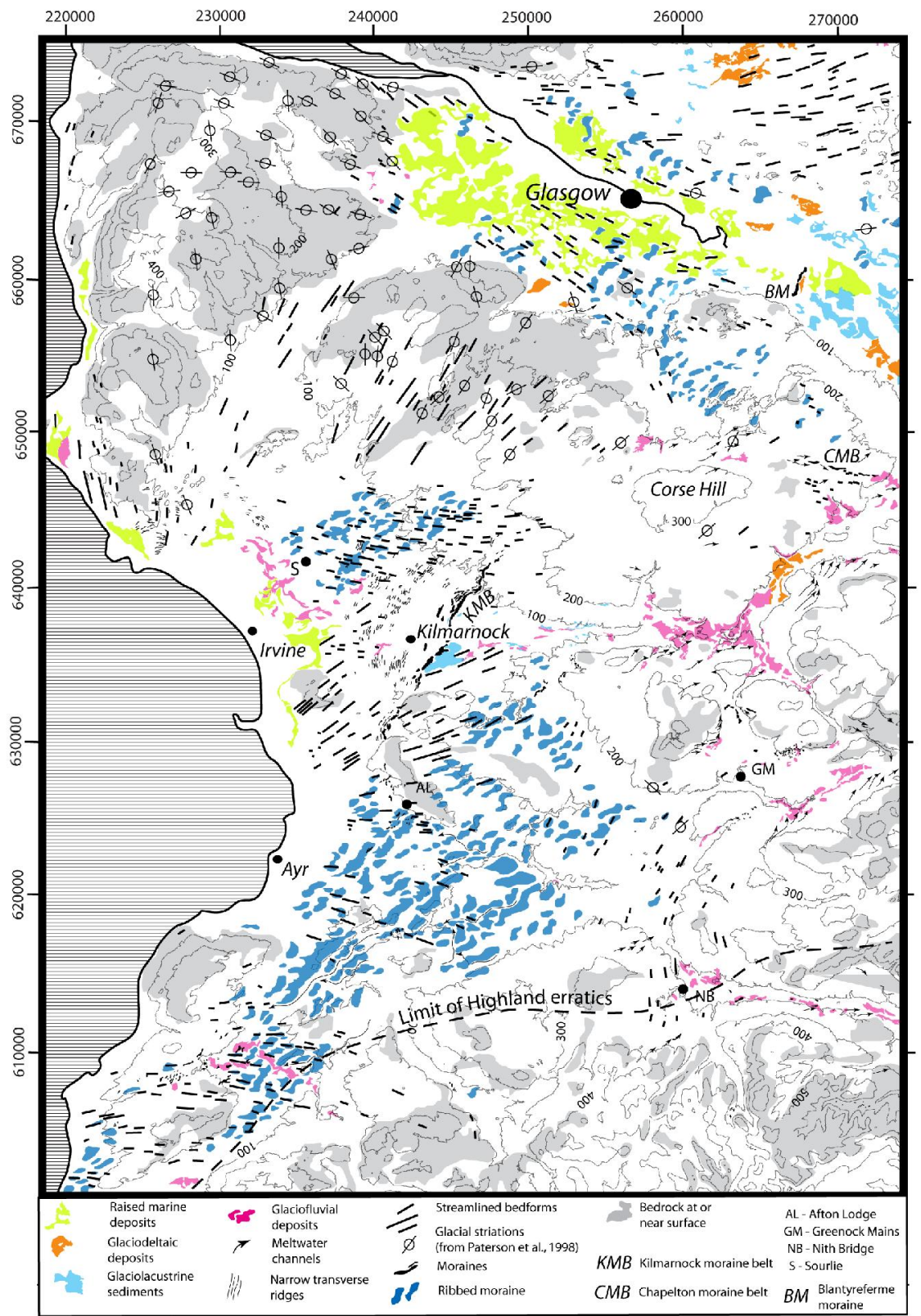

Fig. 5 


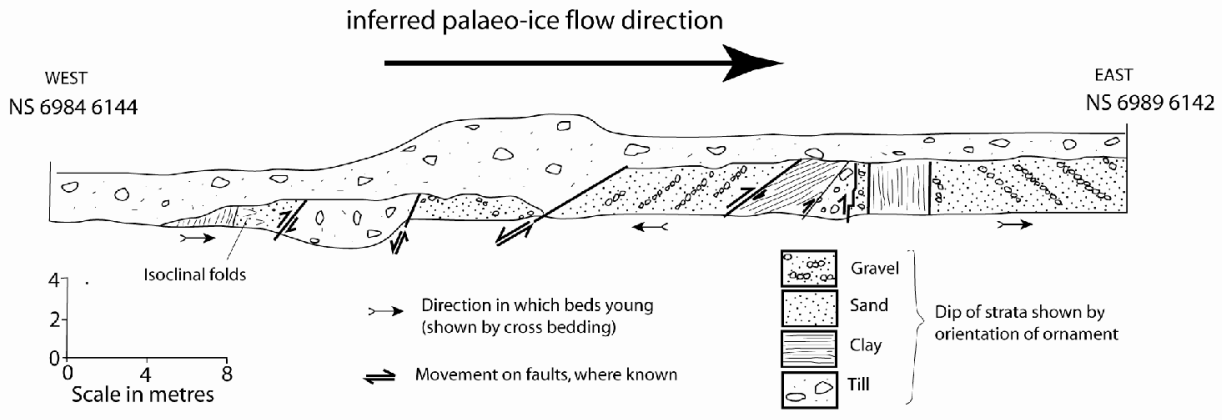

Fig. 6 

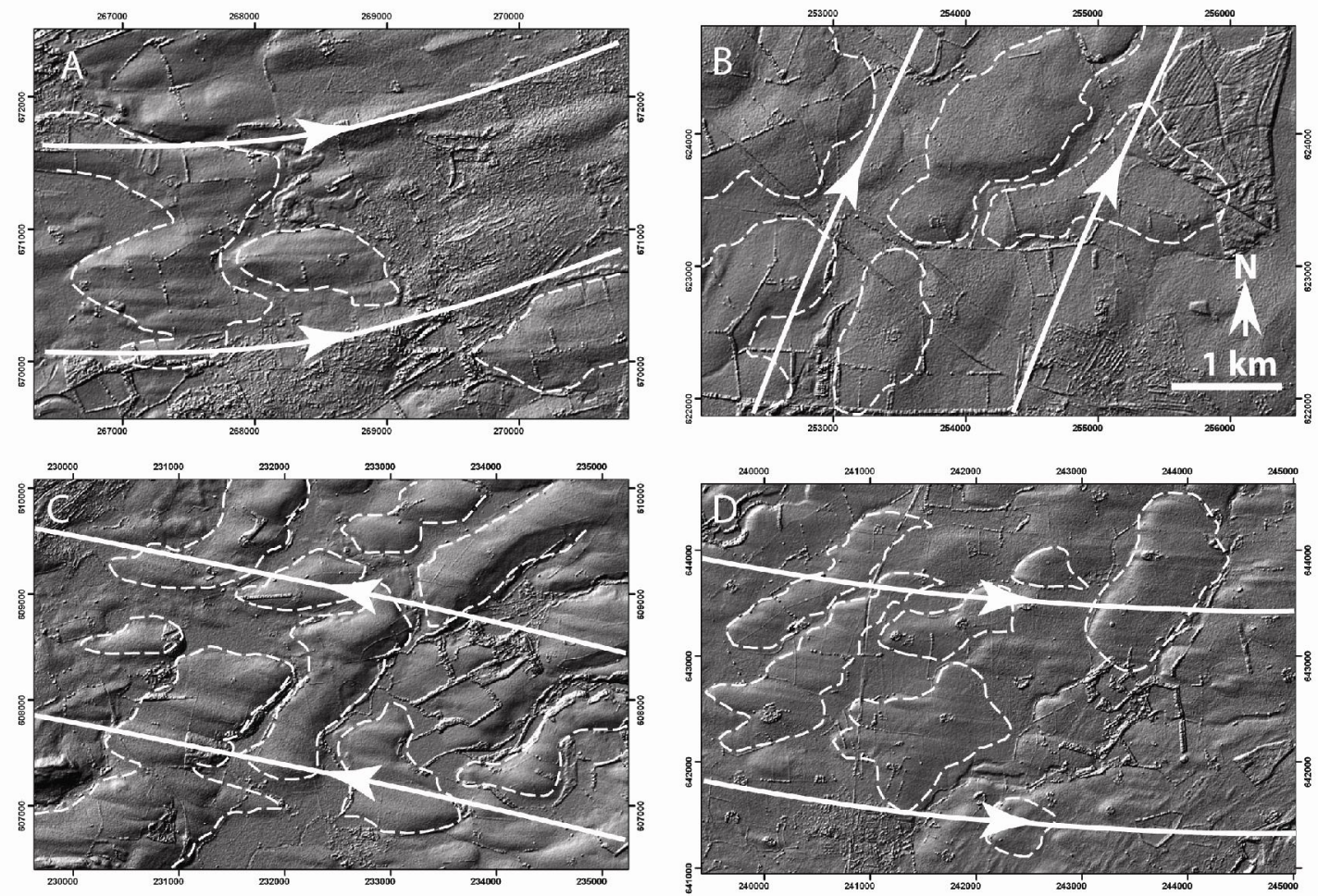

Fig. 7 


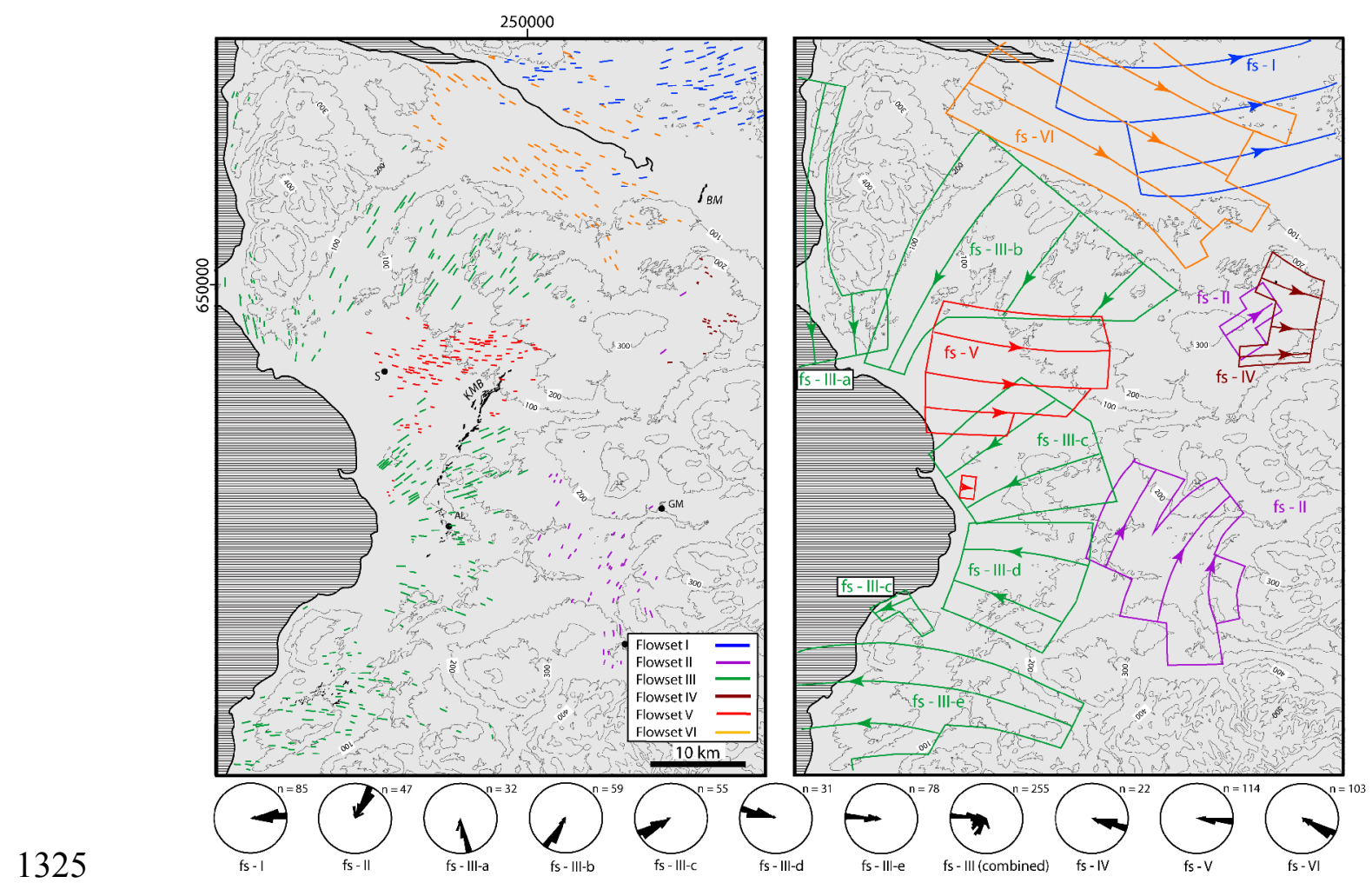

Fig. 8 


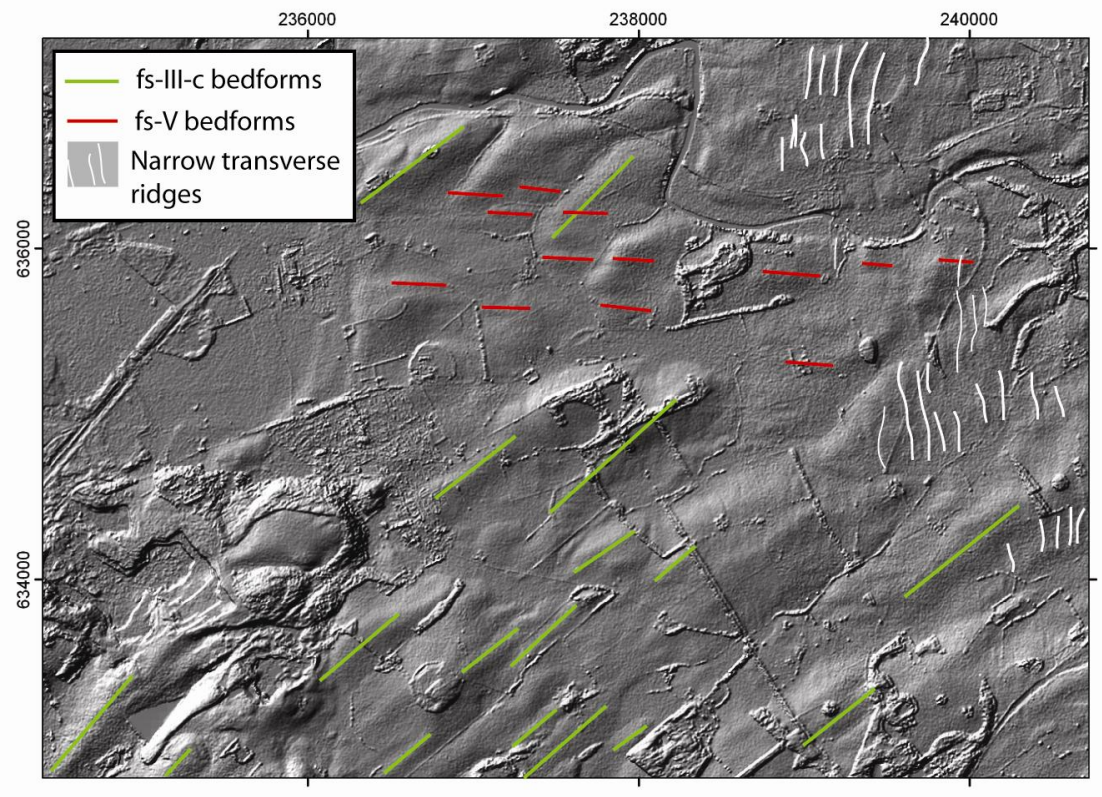

1340

Fig. 9 



Fig. 10 


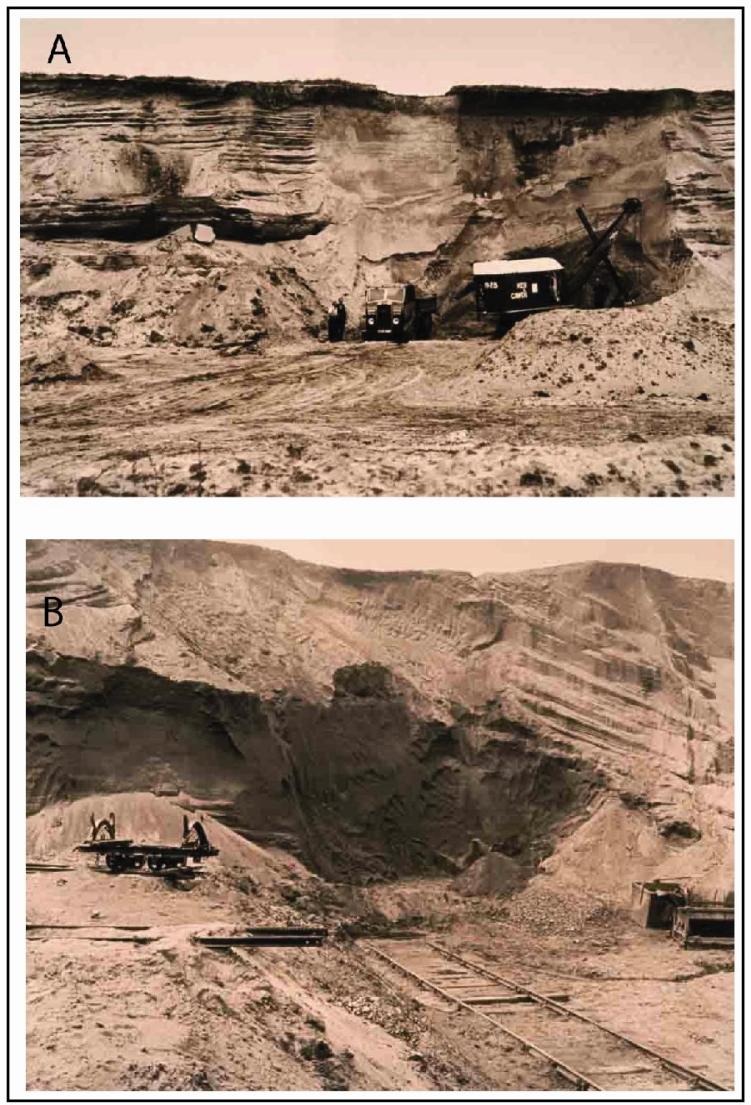

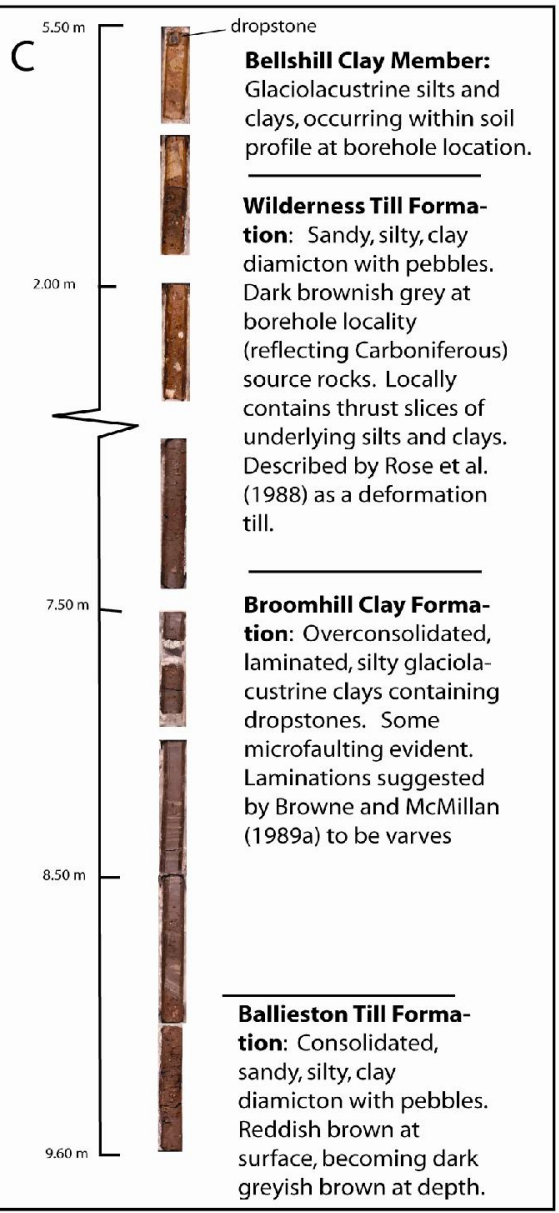

Fig. 11 

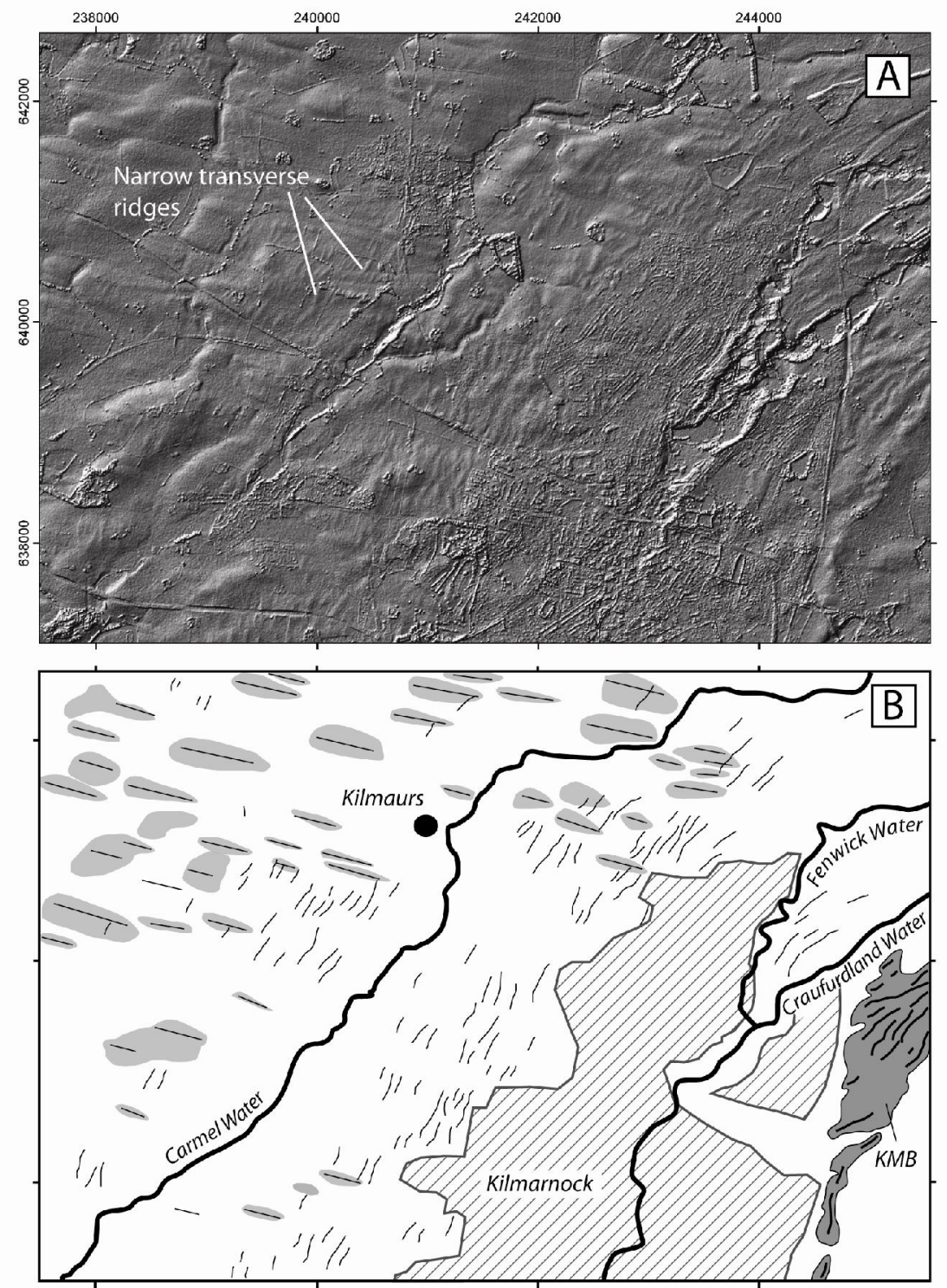

Fig. 12

1355

1360 


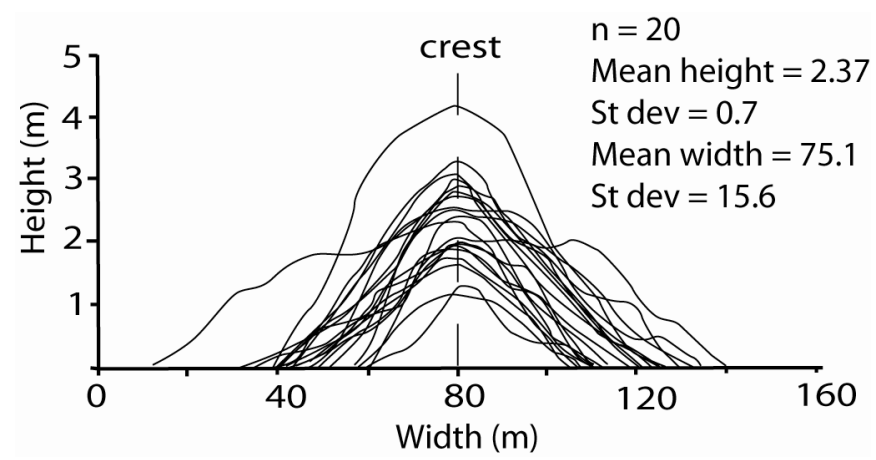

1365 Fig. 13

1370

1375 

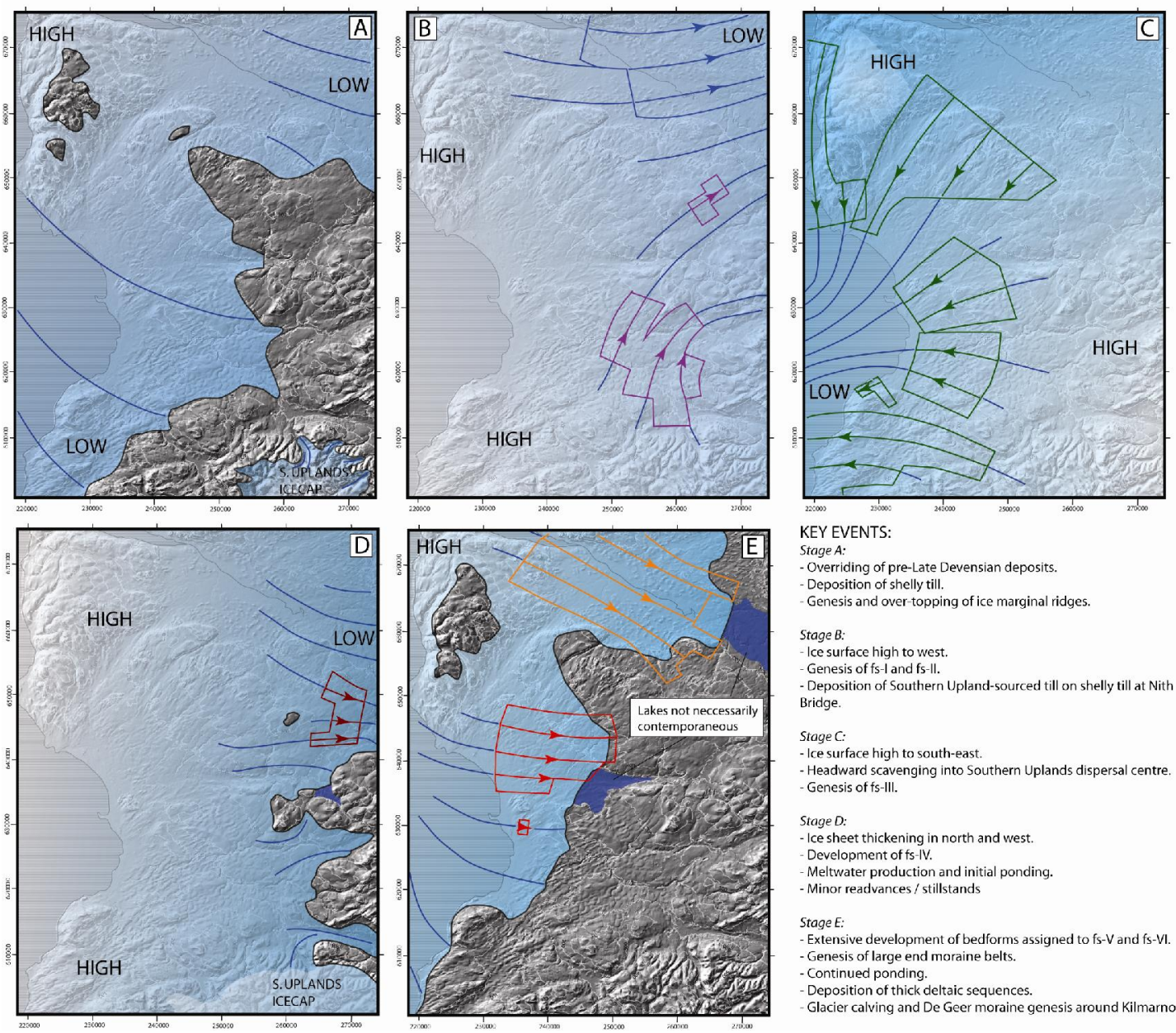

KEY EVENTS

Stage $A$ -

Overriding of pre-Late Devensian deposits.

Deposition of shelly till.

.

Stage $B$ :

Ice surface high to west

- Deposition of Southern Upland-sourced till on shelly till at Nith Bridge.

Stage C:

Ice surface high to south-east

- Headward scavenging into Southern Uplands dispersal centre.

- Ice sheet thickening in north and west.

- Development of fs. IV.

Meltwater production and initial ponding.

Minor readvances / stillstands

Staget:

Extensive development of bedforms assigned to $f_{s}-V$ and $f_{s}-V l$ - Genesis of large end moraine belts.

- Continued ponding.

Glacier calving and De Geer moraine genesis around Kilmarnock

Fig. 14 


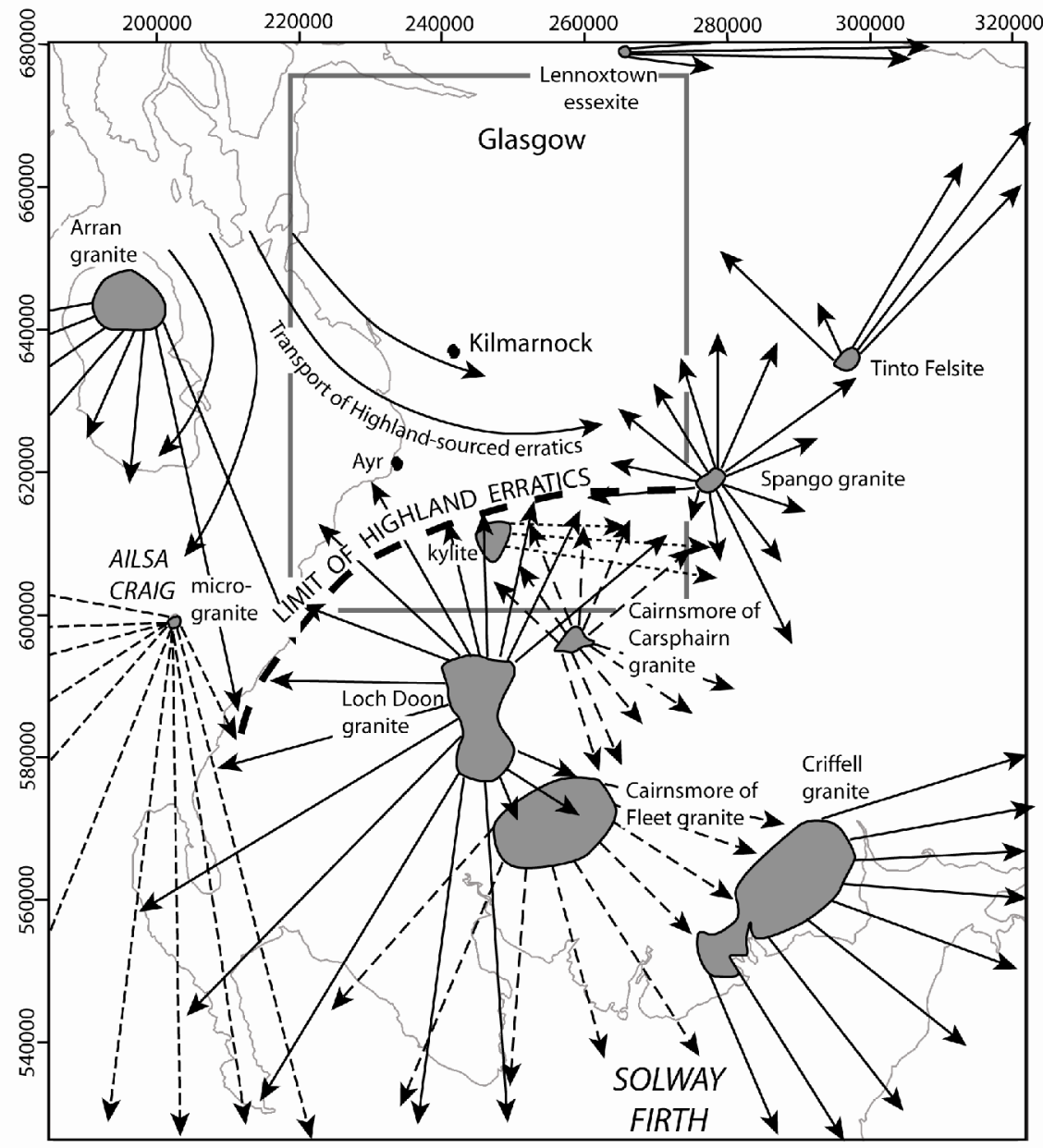

$1385 \quad$ Fig. 15 


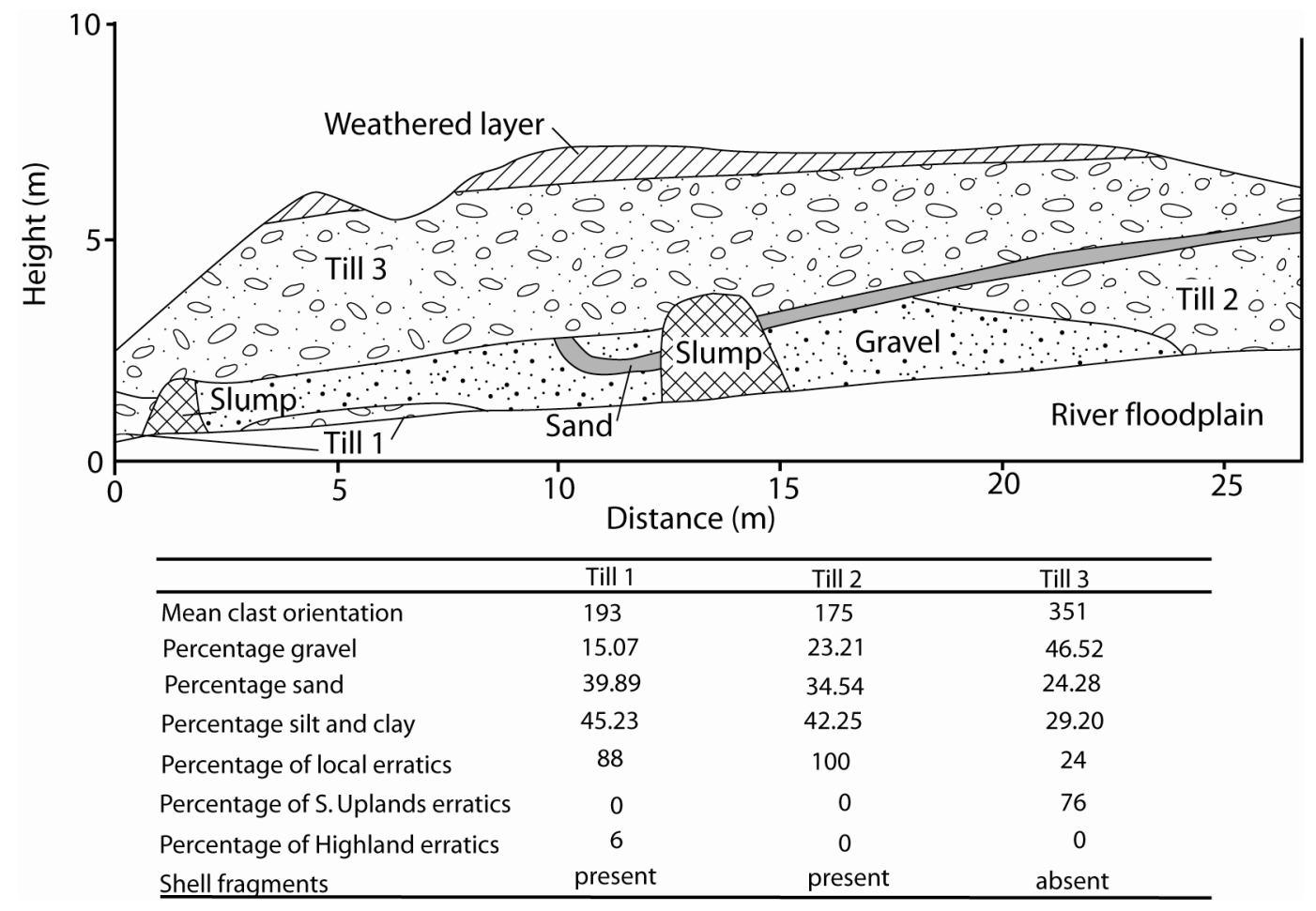

Fig. 16 



Fig. 17 


\begin{tabular}{|c|c|c|c|c|c|c|c|c|c|}
\hline \multirow[t]{2}{*}{ Flowset } & \multicolumn{3}{|c|}{ Length } & \multicolumn{3}{|c|}{ Width } & \multicolumn{3}{|c|}{ ER } \\
\hline & Range & Mean & St Dev & Range & Mean & St Dev & Range & Mean & St Dev \\
\hline Fs -1 & $370-1498$ & 826 & 262 & $75-468$ & 239 & 87 & $2.1-7.6$ & 3.7 & 1.1 \\
\hline Fs - II & $330-1195$ & 563 & 187 & $65-443$ & 307 & 83 & $1.6-7.7$ & 2.9 & 1.0 \\
\hline Fs - III-a & $350-2430$ & 706 & 476 & $76-500$ & 194 & 103 & $2.0-5.3$ & 3.7 & 1.0 \\
\hline Fs - III-b & $379-2391$ & 1017 & 445 & $79-590$ & 274 & 108 & $2.3-6.9$ & 3.8 & 0.9 \\
\hline Fs - III - c & $400-2600$ & 1063 & 367 & $100-467$ & 236 & 78 & $2.5-8.0$ & 4.6 & 1.3 \\
\hline Fs - III-d & $449-1214$ & 766 & 226 & $118-469$ & 250 & 88 & $1.7-5.7$ & 3.3 & 0.9 \\
\hline Fs - III-e & $372-1700$ & 754 & 244 & $72-580$ & 197 & 84 & $2.2-11.6$ & 4.3 & 1.5 \\
\hline $\begin{array}{l}\text { Fs - III } \\
\text { (combined) }\end{array}$ & $350-2600$ & 877 & 384 & $72-590$ & 230 & 96 & $1.7-11.6$ & 4 & 1.3 \\
\hline Fs - IV & $204-487$ & 321 & 86 & $51-134$ & 76 & 22 & $3.1-5.8$ & 4.3 & 0.9 \\
\hline Fs $-\mathrm{V}$ & $167-1142$ & 540 & 179 & $61-290$ & 127 & 39 & $2.3-8.0$ & 4.3 & 1.1 \\
\hline Fs - VI & $290-1206$ & 660 & 155 & 80- 467 & 232 & 79 & $1.7-6.4$ & 3.1 & 0.8 \\
\hline
\end{tabular}

Table 1 